\title{
High Liquidity Creation and Bank Failures
}




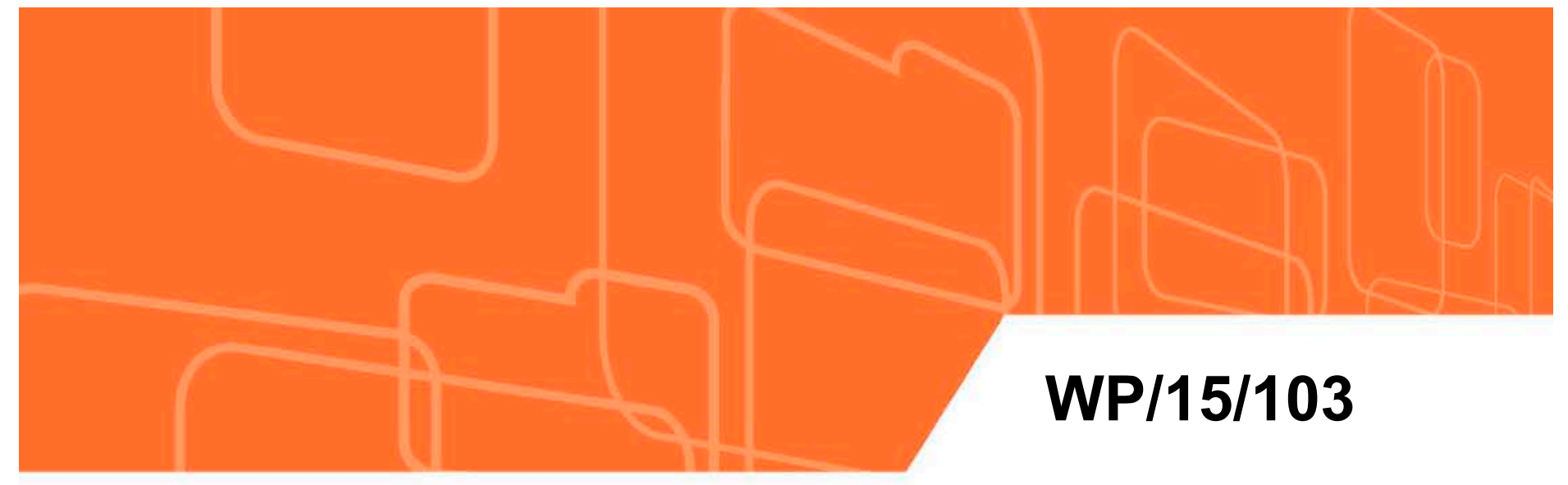

\section{IMF Working Paper}

High Liquidity Creation and Bank Failures

by Zuzana Fungacova, Rima Turk, and Laurent Weill

I N T E R N A T I O N A L M O NETAR Y FU N D 


\title{
IMF Working Paper
}

\author{
European Department
}

\section{High Liquidity Creation and Bank Failures}

\section{Prepared by Zuzana Fungacova, Rima Turk, and Laurent Weill ${ }^{1}$}

Authorized for distribution by Helge Berger

May 2015

IMF Working Papers describe research in progress by the author(s) and are published to elicit comments and to encourage debate. The views expressed in IMF Working Papers are those of the author(s) and do not necessarily represent the views of the IMF, its Executive Board, or IMF management.

\begin{abstract}
We formulate the "High Liquidity Creation Hypothesis" (HLCH) that a proliferation in the core activity of bank liquidity creation increases failure probability. We test the HLCH in the context of Russian banking, which provides a natural field experiment due to numerous failures experienced over the past decade. Using Berger and Bouwman's (2009) liquidity creation measures as a comprehensive proxy for overall bank output, we find that high liquidity creation significantly increases the probability of bank failure; this finding survives multiple robustness checks. Our results suggest that regulatory authorities can mitigate systemic distress and reduce the costs of bank failures to society through early identification of high liquidity creators and enhanced monitoring of their funding and investment activities.
\end{abstract}

JEL Classification Numbers:G21; G28

Keywords: Liquidity Creation, Bank Failures

Authors’ E-Mail Addresses: zuzana.fungacova@bof.fi; rturk@imf.org; laurent.weill@unistra.fr

\footnotetext{
${ }^{1}$ We are grateful to Thierry Bayle, Helge Berger, Daniel Hardy, David Grigorian, Philippe Karam, and participants at the seminar series of the Bank of Finland Institute for Economies in Transition in Helsinki, at the Workshop on "Banking in Emerging Markets: Challenges and Opportunities" in the Higher School of Economics in Moscow, at the Annual Meeting of the Eastern Finance Association in St. Pete Beach, at the FEBS Conference in Paris, at the Infiniti Conference in Aix en Provence, at the FMA European Meeting in Luxembourg for providing valuable comments. We also wish to thank Fatima Keaik (CEF) for editorial support.
} 


\section{Contents}

I. INTRODUCTION

II. LITERATURE REVIEW

III. DATA DESCRIPTION AND METHODOLOGY

A. Data

B. Liquidity Creation Measures

C. Methodology

IV. RESULTS 12

A. Regression Results

B. Alternative Estimations

V. CONCLUSIONS 16

REFERENCES $\underline{17}$

\section{TABLES}

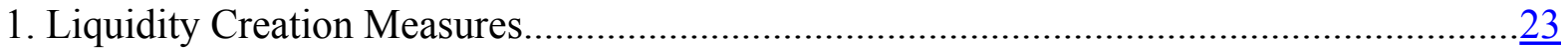

2. Development of the Main Variables .........................................................................24

3. Descriptive statistics of the banks with high liquidity creation and the other .................... 25

4. Liquidity Creation and Bank Failures: Baseline Model ….............................................

5. Liquidity Creation and Bank Failures: Longer Lags .............................................. 27

6. Liquidity Creation and Bank Failures: Alternative Measure of Failure ...........................28

7. Liquidity Creation and Bank Failures: Moscow Banks Only …....................................29

8. Liquidity Creation and Bank Failures: Domestic Private Banks Only ............................. $\underline{30}$

9. Liquidity Creation and Bank Failures: Effect of Deposit Insurance.................................

10. Liquidity Creation and Bank Failures: Effect of Bank Concentration ............................ $\underline{32}$ 


\section{INTRODUCTION}

Identifying vulnerabilities which may lead to bank failure is a persistent challenge to regulators of financial systems and market analysts. Regulators seek timely warning of bank failures for an efficient deployment of monitoring resources and for enhancing regulation enforcement, and shareholders and taxpayers want to avoid substantial resolution costs as well as reduce the time involved in loss resolution.

Two hypotheses in the literature on bank fragility explain bank failures: the "Weak Fundamentals Hypothesis" (WFH) and the "Liquidity Shortage Hypothesis" (LSH). Under the WFH, poor bank fundamentals foreshadow an impending bank failure and CAMELS components are often used as the basis for an early warning system. Bank failures are thus information-based, as decaying capital ratios, reduced liquidity, deteriorating loan quality, and depleted earnings signal an increased likelihood of bank failure. In contrast, the LSH assumes that banks are solvent institutions but fragility is due to the irrational behavior of uninformed depositors who are unable to distinguish between liquidity and solvency shocks. According to this hypothesis, bank vulnerability to crises stems from the financing of illiquid assets with liquid liabilities. When exposed to an external shock and under the sequential servicing constraint, first-in-line depositors seek to withdraw all their deposits and, as the bank's ability to meet deposit withdrawals declines, liquidity shortages become pronounced and the probability of failure increases.

The WFH focuses on asset risk to explain bank fragility and bank risk under the LSH arises from the liability side of the balance sheet. In this paper, we propose that bank vulnerability may result from the interaction between both asset and liability risks. The hypothesis we propose to explain bank distress complements the work of WFH and LSH; it also follows the tradition of Meyer and Pifer (1970) in which financial measure trends are used to discriminate between viable and failing banks. We capture the connectedness of asset and liability risks through a comprehensive measure of liquidity creation - one of the primary functions of banks, according to the financial intermediation literature. Banks create liquidity on their balance sheets by financing relatively illiquid assets with relatively liquid liabilities (Bryant, 1980; Diamond and Dybvig, 1983) or off their balance sheets through loan commitments and other liquidity claims (Kashyap, Rajan, and Stein, 2002). Using new measures on liquidity creation, we postulate that banks' vulnerability to failure may result from a proliferation in the core activity of liquidity creation. We propose the "High Liquidity Creation Hypothesis" (HLCH) to explain bank failures, complementing the WFH (which identifies banks with weak fundamentals) and the LSH (which focuses on the inability of banks to meet liquidity commitments). According to the HLCH, a bank's vulnerability increases when the core output measured by liquidity creation reaches high levels compared to other banks' activities in the system.

The HLCH is built on both theoretical and empirical foundations. On the theoretical side, Diamond and Rajan $(2000,2001,2002)$ argue that carrying illiquid assets and more liquid demand deposits are fundamentally incompatible and add to financial fragility. The model by Allen and Gale (2004) further shows that the role of financial intermediaries as risk transformers and liquidity creators makes them prone to failure. When a bank creates 
liquidity, the likelihood of distress increases and the severity of losses is exacerbated as assets are liquidated to meet liquidity demands. Allen and Gale (2004) even justify regulating bank liquidity provision in the system. ${ }^{2}$

Recent empirical work also suggests that the liquidity creation activity of banks is inextricably coupled with increased risk exposure. Indeed, liquidity creation expands as a bank sells long-term illiquid loans and it is reduced when the bank invests in short-term government bonds (Berger and Bouwman, 2009). However, the risks associated with financing a long-term illiquid loan are generally more pronounced than the risk of investing in short-term government securities. Not only does liquidity creation elevate bank exposure to risk, but Berger and Bouwman (2011) also report that it tends to be high prior to financial crises in the U.S. They propose that curbing liquidity creation may be desirable to contain build-ups in system-wide fragility.

None of the WFH, LSH, or HLCH hypotheses fully define the universe of bank vulnerabilities, but identifying the causes of bank fragility is important in setting the regulatory agenda. The WFH advocates prudential macroeconomic policies that promote bank stability and limit moral hazard incentives. The LSH addresses confidence-building assistance mechanisms to reduce the depositors' incentives for bank runs (deposit insurance, central bank lender-of-last-resort actions, and government bailouts). The HLCH warrants heightened monitoring of liquidity creation in the system. The sooner a bank is identified as a high liquidity creator, the more prompt regulatory action can bring its core activity back to acceptable levels, thereby reducing the likelihood of bank failure and potential taxpayer losses.

To test the HLCH, we need a banking system that witnessed a number of bank failures which are unrelated to economic business cycles or triggered by adverse exogenous shocks. In Russia, over 200 banks failed between 2000 and 2007 and many of those failures were not associated with the business cycle. Thus, the banking system in Russia provides a natural field experiment to test the $\mathrm{HLCH}$ as we are able to isolate the reasons for bank fragility independently from exogenous events. Furthermore, the availability of a rich panel dataset on all Russian banks (in terms of data coverage, frequency, and level of detail) allows for the measurement of liquidity creation. We follow the methodology of Berger and Bouwman (2009) to measure bank core output in the form of liquidity creation using detailed bank-level data. The quarterly frequency of the data on Russian banks enables precise tracking of early developments that lead to the buildup of vulnerabilities and eventually to bank failures. By considering all banks in the system, we also ensure against sample selection bias.

To gauge the impact of high liquidity creation on the probability of bank failures, we perform logit regressions with bank random effects. We use different thresholds to define high liquidity creation in a given quarter, based on the distribution of the entire liquidity creation in the banking system. Our findings confirm the hypothesis that high liquidity creation

\footnotetext{
${ }^{2}$ In contrast, Williamson (1988) argues government intervention may not be warranted even of liquidity provision leads to bank failure.
} 
increases the probability of bank failure, and the results are robust to several validity checks. Rather than suggesting an absolute cut-off value, we propose to screen financial intermediaries based on their liquidity creation ranking in the system. The identification of high liquidity creators allows regulators to at least place these banks on the watch list for enhanced oversight in view of reducing the number of failures in the system and strengthening incumbent institutions.

The rest of the paper is structured as follows. Section 2 reviews the literature. Section 3 presents the data and the methodology. Section 4 discusses the results. Section 5 concludes.

\section{LITERATURE REVIEW}

We group the extant literature on bank failures under the WFH and the LSH. Broadly speaking, the WFH contends banks that fail are ex-ante weaker than surviving banks and they have less robust fundamentals. Key indicators of impending failure are deteriorating levels of capital adequacy, liquidity dry up, worsening of asset quality, and falling profitability. Two seminal papers deserve mentioning. Meyer and Pifer (1970) find that financial ratios are good predictors of the likelihood of bank failures, and Rolnick and Weber (1984) report that markets discipline banks with weak fundamentals as they fail when market conditions deteriorate and asset prices fall. After US regulators introduced CAMELS ratings to assess bank conditions, a number of scholars used traditional proxies for capital adequacy, asset quality, management quality, earnings, liquidity, and sensitivity as a basis for early warning systems. ${ }^{3}$ The findings for emerging markets also document that weak bank fundamentals significantly affect the likelihood of failure. ${ }^{4}$

Other studies in the WFH literature focus on particular fundamentals that might predict bank failure. Estrella, Park, and Peristiani (2000) advocate the use of simple and informative measures of capital adequacy such as leverage and the ratio of capital to gross revenues to predict subsequent bank failures. Wheelock and Wilson (2000) make three observations related to bank survivorship: managerial inefficiency increases the likelihood of bank failure, inefficient banks are less likely to be acquired, and banks close to insolvency are more likely to be acquired. DeYoung (2003) shows that the number of bank failures increases with operational cost inefficiencies for both established and de novo banks.

In the wake of the recent global financial crisis, there has been a resurgence of interest in predicting bank failures using bank fundamentals. DeYoung and Torna (2013) attribute the underlying causes of deterioration in bank condition and subsequent failures to asset-based nontraditional activities such as venture capital, investment banking and asset securitization. Aubuchon and Wheelock (2010) assess the importance of regional economic characteristics

\footnotetext{
${ }^{3}$ See, for example, Avery and Hanweck (1984), Whalen (1991), Thompson (1991, 1992), Cole and Gunther (1995), Wheelock and Wilson (2000), DeYoung (2003), and Oshinsky and Olin (2005).

${ }^{4}$ See Arena (2008) for evidence from Latin America and East Asia; Claeys and Schoors (2007) for Russia; Molina (2002) for Venezuela; and Ozkan-Gunay and Ozkan (2007) for Turkey.
} 
in driving bank failures rather than using bank-specific characteristics. $\mathrm{Ng}$ and Roychowdhury (2014) report that additions to loan loss reserves positively relate to subsequent bank failures. Cole and White (2012) revisit traditional proxies for CAMELS ratings, arguing that they explain bank failures, and find that the most significant predictor of bank fragility is commercial real estate investment.

Unlike the WFH, the LSH attributes bank failures to a liquidity shortage shock that impairs the ability of banks to meet contractual debt obligations. When there is a shock to the real economy, the financing of illiquid assets with liquid liabilities can lead to a liquidity shortage that forces banks to curtail credit (Diamond and Rajan, 2001). In a review of the theory and history of banking crises, Calomiris (2007) identifies two views to explain the causes of liquidity shortages that lead to bank failures during events of contagion, the panic view and the fundamentalist view. Under the panic view, banks fail during fear-driven runs, as the liquidity shortage results from unwarranted deposit withdrawals that are unrelated to bank solvency. Under the fundamentalist view, banks fail during crises following an exogenous adverse change in economic conditions. Fundamental losses to bank borrowers lead to endogenous contractions of deposits and loans, which curb the supply of money and credit thereby resulting in a liquidity shortage.

A large body of evidence supports the LSH, whether the liquidity shortage stems from unwarranted deposit withdrawals or from weakened fundamentals. Early evidence from the Great Depression by Friedman and Schwartz (1963) suggests that bank failures result from unwarranted panic and that failing banks tend to be more illiquid than insolvent. Panics are attributed to "mob psychology" or "mass hysteria" (Kindleberger, 1978). In the conceptual framework of Diamond and Dybvig (1983), banks finance illiquid assets with demandable debts and face a first-come-first-served constraint, leading Postlewaite and Vives (1987) to conclude that bank runs are self-fulfilling prophecies. In a recent study, Vazquez and Federico (2012) provide empirical evidence on the link between liquidity shortage and probability of bank failure during the global financial crisis. Using Basel III's net stable funding ratio as the measure of liquidity, the authors find that banks with weaker liquidity position in the pre-crisis period were more likely to fail during the crisis.

Liquidity shortages can also unfold following an economic downturn that reduces the value of bank assets. As the likelihood of the bank not meeting its commitments increases, depositors exert pressure on it and withdraw their funds. Under the fundamentalist view, bank failures are a rational response to an unfolding economic recession (Gorton, 1988). Calomiris and Gorton (1991) point out that $19^{\text {th }}$ century banking crises were predicted by leading economic indicators. Calomiris and Mason (2003) also contend that most bank failures during the Depression can be explained by weakened fundamentals from holding relatively illiquid and low-quality assets, as well as little capital.

A number of authors have modeled banking panics as an aggregate uncertainty risk that results from business-cycle risk (Jacklin and Bhattacharya, 1988; Hellwig, 1994; and Alonso, 1996), and which is heightened when liquidity needs are high (Chari and Jagannathan, 1988). Allen and Gale's (1998) model assumes that depositors can observe a leading economic indicator that correlates with future asset returns, consistent with the 
business cycle view of bank panics. Fundamental shocks are also the driver of financial crises in Allen and Gale's (2004) general equilibrium framework for understanding crises.

In contrast to the literature that examines bank resilience to shocks, this paper investigates bank failures under normal economic conditions without being triggered by business cycles or other exogenous events. Instead, the failure predictor is endogenous, in the sense that banks are hypothesized to be more fragile as their main activity of liquidity creation proliferates. Bank liquidity has received quite some attention in the literature. Allen and Gale (2004) argue that liquidity (or the lack thereof) serves as a channel through which contagion is spread from bank to bank. A drop in liquidity creation could increase individual and systemic bank failures, thereby curbing credit supply, and leading to economic recessions (Bernanke, 1983; Peek and Rosengren, 2000). Liquidity shocks can similarly result in contagion and a systemic meltdown (Diamond and Rajan, 2005), as well as bear severe distributional effects across large and small firms in the economy (Khwaja and Mian, 2008).

Just as a liquidity shortage can have serious implications for a bank's survival, high liquidity creation may also have severe repercussions. Diamond and Rajan $(2000,2001,2002)$ note that bank liquidity creation is a driver for financial fragility, suggesting that bank failures are more likely to occur when the level of liquidity creation is high. As liquidity creation increases, banks are forced to dispose of their illiquid assets to meet depositor withdrawals, thereby raising the risk of failures when assets become insufficient to meet non-contingent commitments (Allen and Gale, 2004). Empirical evidence that high liquidity creation may be detrimental to bank stability is documented in the literature using private credit as a proxy for liquidity in the system. For example, Cottarelli, Dell'Ariccia, and Vladkove (2005) find that the ratio of credit to GDP increases by 5 to 10 percentage points prior to banking crises. Studies by Demirgüç-Kunt and Detragiache (1998), Drees and Pazarbasioglu (1998), and Kaminsky and Reinhart (1999) similarly establish that credit expansion to the private sector usually precedes banking crises. Recent work by Borio (2014) also contends that high credit growth is an impending leading indicator of bank crises.

Berger and Bouwman (2009) develop a measure of bank liquidity creation as a comprehensive proxy for overall bank output. They show that liquidity creation in the US increased substantially between 1993 and 2003 and they investigate the characteristics of the top $25 \%$ and bottom $25 \%$ liquidity creators among large, medium, and small banks. They find that multi-bank holding companies tend to create the most liquidity, that retail banks create far less liquidity per dollar of assets or equity, and that wholesale banks tend to be low liquidity creators. Banks engaged in mergers and acquisition (M\&A) activity also tend to create more liquidity than banks with no M\&A activity. In a follow-up study, Berger and Bouwman (2011) investigate whether high bank liquidity creation at the aggregate level is a good predictor of a financial crisis, showing that it is more useful than GDP, the federal funds rate, or stock market returns in predicting crises.

In this paper, we propose that individual - not just aggregate - bank liquidity creation may have incremental explanatory power in predicting bank failures, even after controlling for the macroeconomic environment and for reasons that are unrelated to business cycle conditions. The banking sector in Russia serves as a natural field experiment to address our research 
question, given that it has witnessed numerous failures during the relatively tranquil period and stable economic conditions.

\title{
III. DATA DESCRIPTION AND METHODOLOGY
}

\begin{abstract}
A. Data
We use bank-level financial statement data for Russian banks from Interfax, a financial information agency that collects and organizes data from the Central Bank of Russia (CBR). ${ }^{5}$ This is a rich dataset with several advantages. First, it provides data on all banks in Russia, and thus avoids the selection bias problem. Second, the data is available on a quarterly basis, providing an opportunity to track developments preceding bank failures with reasonable precision and within a reasonable time frame to give regulators time to act. Finally, the dataset contains a detailed level of financial information that is necessary for the calculation of Berger and Bouwman's (2009) liquidity creation measures. The breakdown of loan portfolios at Russian banks enables us to distinguish between corporate, household, and government loans; deposits are classified by type (settlement accounts and term deposits); securities portfolios are reported by asset classes; and there is detailed information on the maturity of all liabilities.
\end{abstract}

The original data feature an unbalanced panel for the period starting from the first quarter of 1999 and running to the fourth quarter of 2009. For our analysis, however, we only use the data covering the period between 2000 and 2007 to exclude possible contamination from bank failures stemming from Russia's 1998 financial crisis and from the global financial crisis. ${ }^{6}$ Our objective in this paper is to investigate bank failures that occur under "normal" economic times, i.e. when the banking system is not otherwise subject to a major exogenous shock but is witnessing a proliferation in the production of the its main output measured by liquidity creation.

To make sure that we consider deposit-taking institutions only, we apply a series of filters on our dataset. First, we drop observations for which the ratio of total loans to total assets is lower than 5\%. Second, we exclude observations for which the sum of all deposits equals to 0 . Finally, we drop observations where the capital-to-assets ratio is larger than $100 \%$. Our final sample includes over 33,000 bank-quarter observations.

\footnotetext{
${ }^{5}$ For a more detailed description of the dataset, see Karas and Schoors (2005). See also Karas, Pyle and Schoors (2013) for another use of this dataset to examine the effect of deposit insurance on market discipline.

${ }^{6}$ Despite the fact that Russian banks were not directly exposed to the financial instruments that triggered the global financial turmoil, both the banking sector and the economy as a whole were hit by the crisis in the second half of 2008 due to a sudden lack of access to foreign financing and a significant drop in the price of oil. In September 2008, the Russian government and the CBR began to implement a wide variety of measures to support the stability of the financial system.
} 
We also augment the main dataset using additional information. We identify failed banks from the CBR's list of failed banks, which roughly includes 230 failed institutions distributed over the whole period of study. ${ }^{7}$ Further, we hand-collect data on the location of all banks and their branches from the CBR website. We use this information to control for the regional characteristics of the environments in which banks operate using data from the Russian Federal State Statistics Service (Rosstat).

\section{B. Liquidity Creation Measures}

Following the three-step procedure developed by Berger and Bouwman (2009) to construct measures of liquidity creation for Russian banks, we classify bank activities as liquid, semiliquid or illiquid. ${ }^{8}$ We consider all items included under assets, liabilities, and capital, and make our classification based on the ease, cost, and time necessary for banks (customers) to turn their obligations into liquid funds (withdraw funds), taking into account Russian-specific factors, e.g. we classify some securities as liquid because there is an active market for them.

We next assign weights to all balance sheet items. In line with the theory of financial intermediation that banks create liquidity by transforming illiquid assets to liquid liabilities, we apply positive weights to these two balance sheet categories. In parallel, we assign negative weights to liquid assets, illiquid liabilities, and capital, since bank liquidity creation is destroyed if illiquid liabilities are used to finance liquid assets.

Equation 1 shows the functional form used to construct the bank liquidity creation measures. Liquidity Creation $=\{1 / 2 \times$ Illiquid Assets $+0 \times$ Semi-Liquid Assets $-1 / 2 \times$ Liquid Assets $\}+$ $\{1 / 2 \times$ Liquid Liabilities $+0 \times$ Semi-Liquid Liabilities $-1 / 2 \times$ Illiquid Liabilities $\}-1 / 2 \times$

Capital

Following Berger and Bouwman (2009), we construct two measures of liquidity creation (LC) from Eq. 1, using two definitions for each of the right-hand-side terms. The first liquidity creation measure, $\mathrm{LC} 1$, is based on a category classification of balance sheet items. The second measure, LC2, is a liquidity creation measure that rests on a maturity classification of bank activities. Table 1 provides a detailed description of balance sheet items used to calculate the two liquidity creation measures, their classification according to categories and maturities, and the weights assigned to each grouping.

For LC1, the liquid assets category consists of (a) correspondent accounts with other banks (i.e. central bank, domestic, and foreign banks) (b) investments in government securities, and

\footnotetext{
${ }^{7}$ The last column of Table 2 provides the breakdown of the number of bank failures by quarter.

${ }^{8}$ Unlike Berger and Bouwman (2009), we do not consider off-balance sheet items. For most of the sample period, off-balance sheet activities are insignificant in Russia.
} 
(c) investments in promissory notes. We do not consider investments in non-government securities as their values are quite low for most of the observation period. ${ }^{9}$

In examining loans, we follow the literature and consider corporate loans as illiquid assets since banks generally lack the option of selling them to meet liquidity needs. We classify other types of loans as semi-liquid assets, including consumer loans, loans to the government, and interbank loans. As mortgage lending is quite a recent phenomenon in Russia, the majority of consumer loans here are short-term loans to buy consumer goods. We view consumer loans as semi-liquid following the idea that items with shorter maturity tend to be more liquid than longer-term items, notwithstanding rare loan securitization in Russia. All other assets (calculated as the difference between total assets and the sum of all loans and liquid assets) include fixed assets and are regarded as illiquid items.

On the liability side, we distinguish between three broad categories: claims of banks, claims of the non-banking sector, and debt securities issued by banks. Claims of banks are readily available for withdrawal and fall into the liquid liabilities category. In contrast, claims of the non-banking sector are of two types. The first category includes the settlement accounts of clients (domestic and foreign firms, government, and households). These are classified as liquid because customers can easily withdraw these funds without penalty. The second category of claims of non-banking sector contains term deposits classified as semi-liquid because it may be difficult or costly to withdraw them immediately. The final liabilities category, debt securities issued by banks, consists of promissory notes, deposit and saving certificates, and bonds. Since Russia has liquid markets for promissory notes, we classify these instruments as liquid liabilities. Markets for deposit and savings certificates, as well as bonds, have only emerged in recent years. Issuance of these instruments is insignificant in our sample period, so we categorize these items as semi-liquid liabilities. Following the same logic as on the asset side of the balance sheet, we calculate other liabilities as the difference between total liabilities and the sum of all of the above-mentioned claims and view them as illiquid items, similar to the treatment of bank capital.

Careful examination of the balance sheet information of Russian banks shows a more detailed breakdown of the reporting of some items based on maturity. Maturity-based information provides us with important additional information to define liquidity creation in a more precise manner and construct our second liquidity creation measure, LC2. On the asset side, the maturity breakdown is available for interbank loans only. Thus, we classify all assets other than interbank loans as in LC1. Next, we group interbank loans with a maturity of less than one week in the category of liquid assets, interbank loans with a maturity of more than one year and nonperforming interbank loans are treated as illiquid, and all other interbank loans are labeled as semi-liquid assets.

\footnotetext{
9 Russia's capital markets are still too illiquid for banks to invest in non-government securities. Unlike government securities, banks also have little incentive to hold these securities as they cannot be used as collateral when borrowing from the CBR. Finally, data on investments in non-government securities is only available starting from 2004, i.e. several years into the observation period. Even so, we recalculated the two liquidity creation measures using this data. The results showed trends in line with those of LC1 and LC2.
} 
The classification of liabilities for the LC2 calculation is based solely on maturity. We apply the general principle that items of shorter maturity are more liquid than longer term liabilities. The liquid liabilities category includes term deposits and debt securities with maturities shorter than 90 days, as well as current and correspondent accounts. Liabilities with maturities between 90 days and one year fall into the semi-liquid category, and liabilities with maturities over a year, overdue liabilities, and liabilities with uncertain terms to maturity are classified as illiquid. Like with LC1, we treat bank capital as an illiquid portion of the balance sheet. Both liquidity creation measures, LC1 and LC2, are normalized by total assets for better comparability across banks and to avoid attributing high liquidity creation weight for large banks.

\section{Methodology}

We implement the panel logit methodology to test the HLCH or the effect of high liquidity creation on the probability of bank failure. The dependent variable is a dummy variable equal to 1 if the bank's license is withdrawn in a given quarter and 0 otherwise. Thus, we define a bank as failed when its license is withdrawn. This definition is in line with prior studies on the determinants of bank failures in Russia (e.g. Claeys and Schoors, 2007; Fungacova and Weill, 2013).

To capture high liquidity creation by banks, we generate two dummy variables that correspond to the upper tail of the distribution of our liquidity creation measures in each quarter, $L C$ 80-90\% and $L C$ 90-100\%. These dummy variables are equal to 1 if the liquidity creation measure for a bank in a given quarter ranges between the $80^{\text {th }}$ and $90^{\text {th }}$ percentile, and above the $90^{\text {th }}$ percentile, respectively. Since the literature has established that low liquidity creation may also engender bank failures, we further consider the lower tail of the liquidity creation distribution. We generate two dummy variables $L C_{-} 10-20 \%$ and $L C_{-} O-$ $10 \%$, which are equal to 1 if the liquidity creation measure for a bank in a given quarter falls between the $10^{\text {th }}$ and $20^{\text {th }}$ percentile, and below the $10^{\text {th }}$ percentile, respectively. With the above four dummy variables $\left(L C \_10-20 \%, L C \_0-10 \%, L C \_80-90 \%\right.$, and $\left.L C \_90-100 \%\right)$, we are able to capture banks that suffer from shortages in liquidity creation and those that create high liquidity in the banking system in a given quarter.

The estimations control for bank-specific characteristics that are common in the bank failure literature. We account for bank size using the logarithm of total assets (Size) and for bank profitability with return on assets $(R O A)$. The scale of operations may influence the probability of failure as it affects their ability to diversify the loan portfolios (Calomiris and Mason, 2000), so we expect the sign on the estimated coefficient of Size to be negative. The "too big to fail" thesis supports this expectation and conforms with the view that larger banks are more likely to receive the support of the government and not fail. As for bank profitability, the WFH predicts that weak bank performance to be a major determinant of bank failure. By considering profitability as an ex-ante measure of asset risk (Arena, 2008), we expect a negative association between the probability of bank failure and $R O A$.

We also control for the local market environment, using two variables to account for the local macroeconomic conditions of the regions in which it operates. The regional variable Household Income Growth refers to regional household income per capita; and Small 
Business Growth is the number of small and medium-sized enterprises (SMEs) in a given region multiplied by the average number of employees that SMEs have in that region. To better account for local demand conditions, we need to weigh these two regional variables with the share of bank activities in each region where it operates. About half of Russian banks are headquartered in Moscow and the rest are geographically spread throughout the country, with most of them having a network of branches in different regions. Given that we do not have separate information on the operations of each branch, we use the distribution of branch offices as a proxy for bank output in a given region. Thus, each of the two regional variables for a given bank is thus calculated as a weighted average of its values in the regions in which the bank operates, using the distribution of branch offices as weights. We expect a negative relation between each of the regional variables and the probability of bank failure, as a more favorable macroeconomic environment is expected to foster bank activity and enhance financial stability. We additionally consider local market concentration in the robustness checks. Finally, we include dummy variables for quarters and years to control for seasonal and yearly effects in the estimations.

\section{Results}

Table 2 summarizes the quarterly evolution of LC1 and LC2 normalized by total assets. Between 2000 and 2007, LC1 is consistently larger than LC2, exhibiting an upward trend from 22 to 30 percent of assets whereas LC2 hovers around 18 to 21 percent of assets. LC1 also exhibits more volatility than LC2, which is relatively more stable over the sample period. The growth in both LC ratios results from increasing levels of liquidity creation throughout the sample period at a time where total bank assets are also rising.

To provide a better understanding of high liquidity creators - i.e., those banks for which the dummy variable $L C$ C $90-100 \%$ is equal to 1 , we provide descriptive statistics for their main characteristics in Table 3.

High liquidity creators are larger and less capitalized compared to low liquidity creators. They rely more on stable sources of funds (larger deposit base), with a bias towards deposit funding from firms rather than households. These banks also have greater exposure to credit risk (higher loans-to-assets) and their loan portfolio is geared towards more corporate than individual loans. Overall, they are riskier than other banks as their z-score is lower significantly. On the liquidity side, top liquidity creators carry fewer liquid assets to total assets than other banks, but their liquid liabilities to total assets is significantly higher than incumbent banks. We next present the results of multivariate logit regressions.

\section{A. Regression Results}

In all of the logit regressions, we show the results using the top and bottom percentile ranges for both LC1 and LC2 ratios across four lags (one lag for each of the four quarters preceding a bank failure). We present the results of the baseline models in Table 4. 
The figures in Table 4 indicate that the coefficient estimate of $L C=90-100 \%$ is positive and significant at the $1 \%$ level across all quarters preceding bank failure and using both measures of liquidity creation. The findings suggest that banks with liquidity creation ratios exceeding the $90^{\text {th }}$ percentile of the liquidity creation distribution in the system in all four quarters prior to failure are more likely to fail compared to banks with more moderate levels of liquidity creation. This estimation result lends strong support to the hypothesis that high liquidity creation increases the probability of bank failure. In line with the theoretical work of Allen and Gale (2004) and the empirical evidence from the US (Berger and Bouwman, 2011), the likelihood of bank distress increases when the financing of illiquid assets with liquid liabilities proliferates. The more liquidity banks create, the greater the likelihood of failure. Indeed when financial intermediaries carry a larger share of illiquid loans on their balance sheets, they become more sensitive to liquidity risk; and similarly, when the short-term deposit share in total liabilities increases, banks become more vulnerable to bank runs. Thus, the problem of high liquidity creation ratios might originate from high concentration on either or both sides of a bank's balance sheet. As the bank becomes more focused on its core liquidity creation activity, a detrimental process emerges that increases the probability of failure and may eventually reduce the common pool of liquidity creation in the economy.

In parallel, the estimated coefficient of the lowest liquidity creators in the system, $L C \_010 \%$, is positive and significant in about half of the estimations, providing limited evidence of a positive link between liquidity shortages and the probability of bank failure. This suggests that shortages in liquidity creation may also be associated with a greater probability of failure, i.e. banks with very low liquidity creation ratios are also prone to fail. This finding is not so surprising at second glance. The raison d'être of banks is liquidity creation for the economy, so the inability to perform this function likely signals trouble. ${ }^{10}$ Alternatively, it could be that banks with low liquidity creation ratios rely less on core funding and more on volatile non-deposit long-term sources of funds such as bonds or syndicated loans. While reduced reliance on short-term deposit funding makes a bank less sensitive to bank runs, the large share of alternative sources of financing may increase the bank's exposure to sudden reductions in access to funding and thereby increase the risk of failure (Hahm, Shin, and Shin, 2013). Further, shortages in liquidity creation may stem from a smaller concentration in loans and a larger share in other investments, making the bank more sensitive to market risk.

The control variables that enter our baseline specification are all of the expected sign in corroboration with the former literature (e.g. Arena, 2008). We observe a negative and significant sign for Size and $R O A$ in all estimations. Larger banks have a lower probability of failure, probably because they are either too big to fail or they may have highly diversified loan portfolios and investments. The negative and significant sign on $R O A$ indicates that banks with strong fundamentals are less likely to fail, a finding that accords with the predictions of the WFH and the fact that their higher charter value likely precludes excessive risk-taking. Finally, we do not find significant influence for the regional macroeconomic variables that we account for (household income growth and small business growth).

\footnotetext{
${ }^{10}$ Liquidity shortages can also induce a systemic contagion of failures (Diamond and Rajan, 2005).
} 


\section{B. Alternative Estimations}

We perform a series of alternative estimations to test the sensitivity of our results to alternative specifications. In the first robustness check, we include longer time lags in our baseline model, considering time horizons prior to failure of 15, 18, 21, and 24 months to test whether our results are sensitive to the number of chosen lags chosen. This analysis is important as it provides information on the possible use of liquidity creation measures as early warning indicators. Considering longer time horizons also helps identify at an early stage whether the probability of failure of certain banks increases as a bank gets closer to failure. Table 5 displays the estimations results in line with our main findings. We find support for the HLCH as the sign of the estimated coefficient for $L C=90-100 \%$ is positive and significant across all estimations. The coefficient concerning $L C \_0-10 \%$ is positive but only significant when considering a lag of 21 months.

In the second robustness check, we use an alternative definition of bank failure based on the level of the equity-to-assets ratio to allow for a better coverage of banks with solvency problems, since a decision to revoke a banking license may be influenced by non-economic concerns. For example, Brown and Dinç (2005) show that political considerations play a significant role in delaying government intervention to allow a bank to fail in emerging markets. In choosing an alternative definition of bank failure, we follow the approach of Wheelock and Wilson (2000) in their analysis of bank failure determinants in the US. The authors first consider banks closed by the FDIC (similar to our approach), and then apply an alternative definition of bank failure (a ratio of equity less goodwill to total assets below $2 \%$ ). We use the same threshold and define failed banks in Russia as those institutions with a ratio of equity to total assets below $2 \%$. Table 6 presents the estimations results using this alternative definition of failed banks.

Again, the coefficient on $L C \_90-100 \%$ is positive and significant in all estimations, lending support to the $\mathrm{HLCH}$. We do not observe that banks with very low liquidity creation ratios have a greater probability of failure; $L C \_0-10 \%$ is only significant in one of the estimated specifications.

In the third robustness check, we perform all estimations for Moscow-based banks only. About half of banks in Russia are headquartered in Moscow, and banks in the capital city include the largest financial institutions in the country. Cole and Gunther (1994) note that regulatory flexibility differs for large and small banks, thus justifying the special treatment for Moscow-based banks. Once again, the results (reported in Table 7) are broadly consistent with the $\mathrm{HLCH}$ as $L C \_90-100 \%$ is positive and significant across all estimations, but low liquidity creation has no impact on the incidence of bank failures.

In the fourth robustness check, we consider domestic private banks exclusively in our estimations. It is possible that the probability of bank failure at state-controlled banks and foreign banks is lower than for domestic banks. State-controlled banks may be less likely to fail because of the higher likelihood of state intervention in times of trouble and because of the greater confidence from depositors. Similarly, foreign banks are likely to benefit from the support of their parent institutions abroad. Thus, it could be that the relation between high liquidity creation and the incidence of bank failures is clouded by the presence of state- 
controlled and foreign banks in our sample. Table 8 presents the estimation results for the sub-sample of domestic private banks.

The coefficient on $L C$ _90-100\% is positive and significant at the $1 \%$ level, again corroborating the HLCH. Interestingly, unlike the two former robustness checks, we observe positive and significant coefficients for $L C \_0-10 \%$ in most of the estimations.

In the fifth robustness check, we investigate the effect of introducing the deposit insurance scheme that the Russian authorities implemented in 2004. The consensus among researchers on banking crises tends to suggest that the greater the protection offered by a country's bank safety net, the higher the risk of a banking collapse (e.g. Wheelock and Wilson, 1995; Caprio and Klingebiel, 1996; Demirgüc-Kunt and Detragiache, 2002; Barth, Caprio and Levine, 2006). However the implementation of deposit insurance can also reduce the occurrence of bank failures in Russia by reducing self-fulfilling or information-driven depositor runs. Such mechanism can play a major role in Russia, since the large number of bank failures in the two last decades can have contributed to make depositors particularly prone to react to changes in perceived or effective information on banks. We thus generate a dummy variable (Deposit Insurance) equal to 1 for quarters following the introduction of the deposit insurance scheme, i.e. starting from beginning of 2005, and re-run our baseline model using both liquidity creation measures for four different lags. The results appear in Table 9.

The coefficient for Deposit Insurance is not significant, suggesting that the implementation of a deposit insurance scheme has not influenced the probability of bank failure. We explain this result by the fact that deposit insurance has two opposite effects which offset each other (encouraging bank risk-taking and reducing the probability of bank runs). More importantly, our main findings are reinforced; the estimated coefficient of $L C=90-100 \%$ is still positive and significant across all estimations. We also find some evidence that a shortage in liquidity creation associates with a higher probability of bank failure.

Finally, in deference to the unsettled debate on "competition-fragility" and "competitionstability," we check whether our results are sensitive to controlling for bank concentration. In the context of Russian banking, Fungacova and Weill (2013) provide evidence in support of the "competition-fragility" view using the Lerner index as a measure of bank competition and other concentration indices. ${ }^{11}$ We measure bank concentration by the HerfindahlHirschmann index for assets (Herfindahl) computed at the regional level by applying the same approach as in the case of other regional variables included in our estimations. Table 10 shows the results.

The findings are again in concordance with the $\mathrm{HLCH}$; the sign on $L C_{-} 90-100 \%$ is positive and highly significant across all estimations. These estimations do not support the positive relation between liquidity shortages and the probability of bank failure, as the coefficient on $L C \_0-10 \%$ is only significant once. In parallel, we observe a significant and negative

\footnotetext{
${ }^{11}$ Berger and Bouwman (2009) examine the role of bank concentration in relation to liquidity creation.
} 
coefficient for bank concentration, which is in line with the view that concentration reduces the probability of bank failure in Russia.

Overall, the robustness tests are congruent with our main finding that high liquidity creation increases the probability of bank failure in Russia, irrespective of business cycles and even when the financial system is not subject to an exogenous shock. In all estimations, we show that banks with a liquidity creation measure above the $90^{\text {th }}$ percentile have a significantly greater probability of failure compared to other banks. This result lends support to the HLCH.

The robustness analyses provide very limited evidence in favor of a link between low liquidity creation or liquidity creation shortages and the probability of bank failure. While the main estimations provide some support in favor of such a relation, this result is not maintained under alternative specifications, notably when considering an alternative definition of bank failure, when the sample is limited to Moscow banks only and when bank concentration is accounted for.

\section{CONCLUSIONS}

This paper introduces a new explanation to bank failures related to the core liquidity-creating role of banks, postulated in the "High Liquidity Creation Hypothesis" (HLCH) which asserts that high liquidity creation by banks can increase the probability of failure. Russia experienced bank failures over the past decade, making it an ideal natural field experiment for testing this hypothesis, at the time when the financial system was not subject to an exogenous shock and under normal economic conditions. We propose a screening procedure of banks, ranking them based on their liquidity creation in the system. Specifically, we define high liquidity creators as banks with a liquidity creation level in a given quarter that exceeds the $90^{\text {th }}$ percentile of the distribution. When liquidity creation becomes high, the probability of failure for such a bank increases significantly more than for other banks. Our results are robust to alternative measures of liquidity creation and definitions of bank failure, and controlling for bank location, market concentration, and regulatory changes. They are also in line with the theoretical predictions of Allen and Gale (2004) and empirical results for the U.S. (Berger and Bouwman, 2011).

The HLCH has two main implications. First, it suggests that liquidity creation by banks can be counterproductive when it becomes high. Liquidity creation above a certain threshold increases the probability of bank failure, eventually leading to the disappearance of the high liquidity-creating institution and even a reduction in the volume of aggregate liquidity creation in the economy. Therefore, regulatory authorities may need to give more attention to the liquidity-creating activities by banks when identifying vulnerabilities in the financial system. Second, our main finding provides insight for regulatory authorities to predict bank failures. Specifically, regulators may want to consider incorporating liquidity creation into their early warning systems and subject high liquidity creators to additional oversight to either prevent bank failure or impose an orderly winding-down of the bank and limit taxpayer losses. 


\section{REFERENCES}

Allen, F. and D. Gale, 1998, Optimal Financial Crises, Journal of Finance 53, 1245-84.

Allen, F. and D. Gale, 2004, Financial Intermediaries and Markets, Econometrica 72, 102361.

Alonso, I., 1996, On Avoiding Bank Runs, Journal of Monetary Economics 37, 73-87.

Arena, M., 2008, Bank Failures and Bank Fundamentals: A Comparative Analysis of Latin America and East Asia during the Nineties using Bank-Level Data, Journal of Banking and Finance 32, 229-310.

Aubuchon, C. and D. Wheelock, 2010, The Geographic Distribution and Characteristics of U.S. Bank Failures, 2007-2010: Do Bank Failures Still Reflect Local Economic Conditions? Federal Reserve Bank of St. Louis Review, 395-416.

Avery, R. and G. Hanweck, 1984, A Dynamic Analysis of Bank Failures, Proceedings of the 20th Annual Conference on Bank Structure and Competition, Federal Reserve Bank of Chicago, 380-395.

Barth, J., G. Caprio, and R. Levine, 2006, Rethinking Bank Regulation: Till Angels Govern, New York: Cambridge University Press.

Berger, A. and C. Bouwman, 2009, Bank Liquidity Creation, Review of Financial Studies 22, 3779-3837.

Berger, A. and C. Bouwman, 2011, Bank Liquidity Creation, Monetary Policy, and Financial Crises, Working Paper, Wharton Financial Institutions Center.

Bernanke, B., 1983, Nonmonetary Effects of the Financial Crisis in Propagation of the Great Depression, American Economic Review 73(3), 257-76. 
Borio, C., 2014, The Financial Cycle and Macroeconomics: What Have We Learnt? Journal of Banking \& Finance 45, 182-198.

Brown, C. and S. Dinç, 2005, The Politics of Bank Failures: Evidence from Emerging Markets, Quarterly Journal of Economics 120(4), 1413-1442.

Bryant, J., 1980, A Model of Reserves, Bank Runs, and Deposit Insurance, Journal of Banking and Finance 4, 335-344.

Calomiris, C., 2007, Bank Failures in Theory and History: The Great Depression and Other “Contagious" Events, NBER Working Papers 13597, National Bureau of Economic Research.

Calomiris, C. and G. Gorton, 1991, The Origins of Banking Panics, Models, Facts, and Banking Regulation, in R.G. Hubbard (ed.), Financial Markets and Financial Crises, Chicago, IL: University of Chicago Press.

Calomiris, C. and J. Mason, 2003, Fundamentals, Panics and Bank Distress during the Depression, American Economic Review 93, 1615-47.

Caprio, G. and D. Klingebiel, 1996, Bank Insolvencies: Cross-Country Experience, Policy Research Working Paper No.1620. Washington, D.C.: World Bank.

Chari, V. and R. Jagannathan, 1988, Banking Panics, Information, and Rational Expectations Equilibrium, Journal of Finance 43, 749-60.

Claeys,, S. and K. Schoors, 2007, Bank Supervision Russian Style: Evidence of Conflicts between Micro- and Macro-Prudential Concerns, Journal of Comparative Economics $35,630-657$.

Cole, R. and J. Gunther, 1994, When Are Failing Banks Closed? Federal Reserve Bank of Dallas, Financial Industry Studies, 1-12. 
Cole, R. and J. Gunther, 1995, Separating the Likelihood and Timing of Bank Failure, Journal of Banking and Finance 19, 1073-89.

Cole, R. and L. White, 2012, Déjà Vu All Over Again: The Causes of U.S. Commercial Bank Failures This Time Around, Journal of Financial Services Research 42, 5-29.

Cottarelli, C., Dell'Ariccia, G. and I. Vladkova-Hollar, 2005, Early Birds, Late Risers, and Sleeping Beauties: Bank Credit Growth to the Private Sector in Central and Eastern Europe and in the Balkans, Journal of Banking and Finance 29, 83-104.

Demirgüç-Kunt, A., and E. Detragiache, 1998, The Determinants of Banking Crises in Developing and Developed Countries, IMF Staff Papers 45 (1), 81-109.

Demirgüç-Kunt, A. and E. Detragiache, 2002, Does Deposit Insurance Increase Banking System Stability? An Empirical Investigation, Journal of Monetary Economics 49, 1373-1406.

DeYoung, R. ,2003, De Novo Bank Exit, Journal of Money, Credit, and Banking 35, 71128.

DeYoung, R., and G. Torna, 2013, Nontraditional Banking Activities and Bank Failures during the Financial Crisis, Journal of Financial Intermediation 22(3), 397-421.

Diamond, D. and P. Dybvig, 1983, Bank Runs, Deposit Insurance, and Liquidity, Journal of Political Economy 91, 401-19.

Diamond, D. and R. Rajan, 2000, A Theory of Bank Capital, Journal of Finance 55, 243165.

Diamond, D. and R. Rajan, 2001, Liquidity Risk, Liquidity Creation and Financial Fragility: A Theory of Banking, Journal of Political Economy 109, 287-327. 
Diamond, D. and R. Rajan, 2002, Bank Bailouts and Aggregate Liquidity, American Economic Review 92(2), 38-41.

Diamond, D. and R. Rajan, 2005, Liquidity Shortages and Banking Crises, Journal of Finance 20(2), 615-646.

Drees, B., and C. Pazarbasioglu, 1998, The Nordic Banking Crises: Pitfalls in Financial Liberalization? IMF Occasional Paper No. 161 (Washington D.C.: International Monetary Fund).

Estrella, A., Park S. and S. Peristiani, 2000, Capital Ratios as Predictors of Bank Failure. Economic Policy Review, Federal Reserve Bank of New York, 33-5.

Friedman, M. and A. Schwartz, 1963, A Monetary History of the United States, 1867-1960. Princeton, NJ: Princeton University Press, 1963.

Fungacova, Z. and L. Weill, 2013, Does Competition Influence Bank Failures? Evidence from Russia, Economics of Transition 21(2), 301-322.

Gorton, G., 1988, Banking Panics and Business Cycles, Oxford Economic Papers 40, 751-81. Hahm, J., Shin, H. and K. Shin, 2013, Non-Core Bank Liabilities and Financial Vulnerability, Journal of Money, Credit and Banking 45(1), 3-36.

Hellwig, M., 1994, Liquidity Provision, Banking, and the Allocation of Interest Rate Risk, European Economic Review 38, 1363-89.

Jacklin, C. and S. Bhattacharya, 1988, Distinguishing Panics and Information-Based Bank Runs: Welfare and Policy Implications, Journal of Political Economy 96, 568-92.

Kaminsky, G., and C. Reinhart, 1999, The Twin Crises: the Causes of Banking and Balance of Payments Problems, The American Economic Review 89, 473-500. 
Karas, A. and K. Schoors, 2005, Heracles or Sisyphus? Finding, Cleaning and Reconstructing a Database of Russian Banks, Ghent University Working Paper $05 / 327$.

Karas, A., Pyle, W. and K. Schoors, 2013, Deposit Insurance, Banking Crises, and Market Discipine: Evidence from a Natural Experiment on Deposit Flows and Rates, Journal of Money, Credit and Banking 45(1), 179-200.

Kashyap, A., Rajan, R. and J. Stein, 2002, Banks as Liquidity Providers: An Explanation for the Coexistence of Lending and Deposit-Taking, Journal of Finance 57, 33-73.

Khwaja, I. and A. Mian, 2008, Tracing the Impact of Bank Liquidity Shocks: Evidence from an Emerging Market, American Economic Review 98(4), 1413-42.

Kindleberger, C., 1978, Manias, Panics, and Crashes. A History of Financial Crises, New York: Basic Books.

Meyer, P. and H. Pifer, 1970, Prediction of Bank Failures, Journal of Finance 25(4), 853-68.

Molina, C., 2002, Predicting Bank Failures using a Hazard Model: The Venezuelan Banking Crisis, Emerging Markets Review 3, 31-50.

Ng, J. and S. Roychowdhury, 2014, Do Loan Loss Reserves Behave like Capital? Evidence from Recent Bank Failures, Review of Accounting Studies 19(3), 1234-1279.

Oshinsky, R., and V. Olin, 2005, Troubled Banks: Why Don't They All Fail? Federal Deposit Insurance Corporation Banking Review 18, 22.

Ozkan-Gunay, E. and M. Ozkan, 2007, Prediction of Bank Failures in Emerging Financial Markets: An ANN Approach, The Journal of Risk Finance 8, 465-80.

Peek, R. and E. Rosengren, 2000, Collateral Damage: Effects of the Japanese Bank Crisis on Real Activity in the United States, American Economic Review 90(1), 30-45. 
Postlewaite, A. and X. Vives, 1987, Bank Runs as an Equilibrium Phenomeno, Journal of Political Economy 95, 485-91.

Rolnick, A. and W. Weber, 1984, The Causes of Free Bank Failures: A Detailed Examination, Journal of Monetary Economics 14, 267-92.

Thomson, J., 1991, Predicting Bank Failures in the 1980's. Federal Reserve Bank of Cleveland, Economic Review 27, 9-20.

Thomson, J., 1992, Modeling the Bank Regulator's Closure Option: A Two-Step Logit Regression Approach, Journal of Financial Services Research 6, 5-23.

Vazquez, F. and P. Federico, 2012, Bank Funding Structures and Risk: Evidence from the Global Financial Crisis, IMF Working Paper 12/29.

Whalen, G., 1991, A Proportional Hazards Model of Bank Failure: An Examination of its Usefulness as an Early Warning Tool, Federal Reserve Bank of Cleveland, Economic Review, 20-31.

Wheelock, D. and P. Wilson, 1995, Explaining Bank Failures: Deposit Insurance, Regulation, and Efficiency, Review of Economics and Statistics 77(4), 689-700.

Wheelock, D. and P. Wilson, 2000, Why Do Banks Disappear? The Determinants of U.S. Bank Failures and Acquisitions, Review of Economics and Statistics 82(1), 127-38.

Williamson S., 1988, Liquidity, Banking, and Bank Failures, International Economic Review 29(1), 25-43. 


\section{Table 1. Liquidity Creation Measures}

This table classifies all balance sheet items in terms of their liquidity. The weight of each category is given in parentheses and it is used to calculate two liquidity creation measures following Equation (1). LC1 denotes the category-based liquidity creation measure, where bank activities are classified based on different categories. LC2 is the maturity-based liquidity creation measure, and it rests on a category as well as maturity classification for interbank loans and all liabilities.

\begin{tabular}{|c|c|c|c|}
\hline \multirow{8}{*}{ 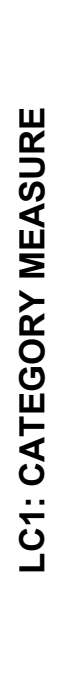 } & Illiquid assets (1/2) & Semi-liquid assets (0) & Liquid assets $(-1 / 2)$ \\
\hline & Loans to firms & Interbank loans & $\begin{array}{c}\text { Correspondent accounts with other } \\
\text { banks }\end{array}$ \\
\hline & Other assets & Loans to government & $\begin{array}{c}\text { Government securities (incl. } \\
\text { securities issued by regions and } \\
\text { municipalities) }\end{array}$ \\
\hline & & Loans to individuals & Investments in promissory notes \\
\hline & Liquid liabilities (1/2) & Semi-liquid liabilities (0) & Illiquid liabilities and capital (-1/2) \\
\hline & $\begin{array}{l}\text { Debt securities issued } \\
\text { (promissory notes) }\end{array}$ & $\begin{array}{l}\text { Debt securities issued } \\
\text { (deposit and saving } \\
\text { certificates, bonds) }\end{array}$ & Other liabilities \\
\hline & $\begin{array}{l}\text { Claims of non-bank sector: } \\
\text { settlement accounts (firms, } \\
\text { households, government) }\end{array}$ & $\begin{array}{l}\text { Claims of non-bank sector: } \\
\text { term deposits accounts } \\
\text { (firms, households, } \\
\text { government) }\end{array}$ & Capital \\
\hline & Claims of banks & & \\
\hline \multirow{8}{*}{ 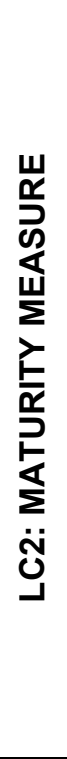 } & Illiquid assets (1/2) & Semi-liquid assets (0) & Liquid assets $(-1 / 2)$ \\
\hline & $\begin{array}{l}\text { Interbank loans (maturity } \\
\text { more than } 1 \text { year) }\end{array}$ & $\begin{array}{c}\text { Interbank loans (maturity } \\
\text { more than a week and less } \\
\text { than } 1 \text { year) }\end{array}$ & $\begin{array}{c}\text { Interbank loans (maturity less than a } \\
\text { week) }\end{array}$ \\
\hline & Loans to firms & Loans to government & $\begin{array}{c}\text { Correspondent accounts with other } \\
\text { banks }\end{array}$ \\
\hline & Other assets & Loans to individuals & $\begin{array}{c}\text { Government securities (incl. } \\
\text { securities issued by regions and } \\
\text { municipalities) }\end{array}$ \\
\hline & & & Investments in promissory notes \\
\hline & Liquid liabilities (1/2) & Semi-liquid liabilities (0) & Illiquid liabilities and capital (-1/2) \\
\hline & $\begin{array}{l}\text { Liabilities with maturity } \\
\text { lower than } 90 \text { days }\end{array}$ & $\begin{array}{l}\text { Liabilities (term deposits } \\
\text { and debt securities) with } \\
\text { maturity less than } 1 \text { year }\end{array}$ & $\begin{array}{c}\text { Liabilities (term deposits, debt } \\
\text { securities) with maturity more than } 1 \\
\text { year and overdue liabilities and } \\
\text { liabilities with uncertain term to } \\
\text { maturity }\end{array}$ \\
\hline & $\begin{array}{l}\text { Current and corresponding } \\
\text { accounts }\end{array}$ & & Capital \\
\hline
\end{tabular}




\section{Table 2. Development of the Main Variables}

This table presents the development of the main variables employed in our analysis. As explained in Table 1, $L C 1$ and $L C 2$ are the category and maturity liquidity creation measures, respectively. They are expressed as proportion of total assets. Size denotes total assets in millions of rubles. We also report the number of failed banks that occurred in every quarter by considering those failed banks for which data are available four quarters before the failure.

\begin{tabular}{|c|c|c|c|c|c|}
\hline & Obs. & $\begin{array}{l}\text { LC1/assets } \\
\text { (mean in \%) }\end{array}$ & $\begin{array}{l}\text { LC2/assets } \\
\text { (mean in \%) }\end{array}$ & Size & $\begin{array}{c}\text { Number of } \\
\text { failures }\end{array}$ \\
\hline $2000 q 1$ & 1214 & 20.91 & 17.50 & 1280.7 & 14 \\
\hline $2000 q 2$ & 1222 & 21.30 & 17.89 & 1389.5 & 7 \\
\hline $2000 q 3$ & 1227 & 22.49 & 18.84 & 1597.7 & 9 \\
\hline $2000 q 4$ & 1218 & 21.63 & 18.23 & 1739.4 & 8 \\
\hline $2001 q 1$ & 1217 & 23.64 & 19.83 & 1882.7 & 3 \\
\hline $2001 q 2$ & 1223 & 23.44 & 19.71 & 2031.5 & 6 \\
\hline $2001 q 3$ & 1219 & 24.37 & 20.51 & 2207.4 & 8 \\
\hline $2001 q 4$ & 1227 & 23.70 & 20.03 & 2348.0 & 6 \\
\hline $2002 q 1$ & 1149 & 25.38 & 20.60 & 2605.7 & 5 \\
\hline $2002 q 2$ & 1227 & 25.72 & 21.01 & 2658.8 & 8 \\
\hline $2002 q 3$ & 1235 & 25.96 & 21.10 & 2786.1 & 5 \\
\hline $2002 q 4$ & 1231 & 25.53 & 20.54 & 3074.9 & 6 \\
\hline $2003 q 1$ & 1228 & 26.27 & 21.42 & 3349.4 & 3 \\
\hline $2003 q 2$ & 1233 & 26.08 & 21.04 & 3630.7 & 5 \\
\hline $2003 q 3$ & 1229 & 27.04 & 21.21 & 3920.2 & 5 \\
\hline $2003 q 4$ & 1234 & 25.22 & 20.04 & 4196.0 & 5 \\
\hline $2004 q 1$ & 1238 & 26.34 & 19.94 & 4436.6 & 3 \\
\hline $2004 q 2$ & 1225 & 28.12 & 20.72 & 4664.4 & 4 \\
\hline $2004 q 3$ & 1208 & 26.16 & 18.19 & 4951.8 & 10 \\
\hline $2004 q 4$ & 1198 & 25.01 & 18.80 & 5488.3 & 12 \\
\hline $2005 q 1$ & 1197 & 26.02 & 18.21 & 5886.5 & 11 \\
\hline $2005 q 2$ & 1191 & 26.89 & 18.41 & 6429.5 & 5 \\
\hline $2005 q 3$ & 1175 & 26.65 & 17.68 & 7059.0 & 19 \\
\hline $2005 q 4$ & 1163 & 25.27 & 17.43 & 7803.9 & 6 \\
\hline $2006 q 1$ & 845 & 30.35 & 18.39 & 11127.6 & 7 \\
\hline $2006 q 2$ & 850 & 30.11 & 18.82 & 12175.8 & 14 \\
\hline $2006 q 3$ & 934 & 29.35 & 18.41 & 12060.9 & 12 \\
\hline $2006 q 4$ & 984 & 28.05 & 19.11 & 13171.9 & 9 \\
\hline $2007 q 1$ & 996 & 29.59 & 18.74 & 14435.8 & 3 \\
\hline $2007 q 2$ & 995 & 29.69 & 18.96 & 16026.3 & 4 \\
\hline $2007 q 3$ & 987 & 30.56 & 19.40 & 17020.2 & 7 \\
\hline $2007 q 4$ & 983 & 28.60 & 18.63 & 19276.4 & 4 \\
\hline
\end{tabular}




\section{Table 3. Descriptive statistics of the banks with high liquidity creation and the other banks}

This table provides descriptive statistics for banks that are high liquidity creators (i.e. liquidity creation measure for a bank in a given quarter is above the $90^{\text {th }}$ percentile of the liquidity creation distribution for all banks) and for the other banks. High liquidity creators are defined using category liquidity creation measure (panel A) and maturity liquidity creation measure (panel B). We test if the values of listed variables are significantly different for high liquidity creation banks and the other banks using t-test with unequal variances. All variables are in percent except for Size and Z-score.

\begin{tabular}{|c|c|c|c|}
\hline \multicolumn{4}{|c|}{$\begin{array}{l}\text { Panel A: Category Liquidity Creation Measure } \\
\text { (LC1) }\end{array}$} \\
\hline & \multicolumn{2}{|c|}{ High Liquidity Creators } & Other Banks \\
\hline Equity/total assets & 13.45 & $* * *$ & 29.79 \\
\hline Size (In of assets) & 6.83 & $* \star *$ & 5.76 \\
\hline Loans/total assets & 59.49 & $* * *$ & 46.48 \\
\hline Deposits/total assets & 52.24 & $* * \star$ & 51.50 \\
\hline Liquid assets/total assets & 10.94 & $* * *$ & 26.44 \\
\hline Liquid liabilities/assets & 50.41 & $* * *$ & 37.49 \\
\hline Z-score & 20.05 & $* * *$ & 33.42 \\
\hline Loans to firms/assets & 54.59 & $* * \star$ & 38.90 \\
\hline Loans to households/assets & 4.32 & $* * \star$ & 6.95 \\
\hline Households deposits/assets & 12.24 & $* * *$ & 15.67 \\
\hline Firm deposits/assets & 37.14 & ${ }^{* * *}$ & 34.41 \\
\hline \multicolumn{4}{|c|}{ Panel B: Maturity Liquidity Creation Measure (LC2) } \\
\hline & High Liquidity & Creators & Other Banks \\
\hline Equity/total assets & 14.72 & ${ }^{* * *}$ & 29.63 \\
\hline Size (In of assets) & 6.08 & *** & 5.84 \\
\hline Loans/total assets & 55.37 & $* * *$ & 46.94 \\
\hline Deposits/total assets & 63.06 & $* * *$ & 50.33 \\
\hline Liquid assets/total assets & 13.14 & $* * *$ & 26.18 \\
\hline Liquid liabilities/assets & 48.78 & *** & 37.68 \\
\hline Z-score & 20.03 & $* * *$ & 33.40 \\
\hline Loans to firms/assets & 49.89 & *** & 39.43 \\
\hline Loans to households/assets & 4.83 & $* \star *$ & 6.89 \\
\hline Households deposits/assets & 16.85 & $* * *$ & 15.17 \\
\hline Firm deposits/assets & 42.96 & $* * *$ & 33.78 \\
\hline
\end{tabular}




\section{Table 4. Liquidity Creation and Bank Failures: Baseline Model}

Logit estimations are performed under the random effects assumption. The dependent variable is a dummy variable, bank failure that is equal to one when the bank's license is revoked and zero otherwise. $L C 1$ denotes the category-based liquidity creation measure. $L C 2$ is the maturity-based liquidity creation measure. These measures enter into the regressions as dummy variables depending on their distribution across several percentiles. Size is the logarithm of total assets; ROA is return on assets; Small business growth is the growth in regional SMEs; and Household Income Growth is the growth in regional household income per capita. Marginal effects of a change in the relevant explanatory variable are reported. Standard errors appear in square brackets below estimated coefficients. *, **,*** denote an estimate significantly different from 0 at the $10 \%, 5 \%$, and $1 \%$ level, respectively. Dummy variables for quarters and years are included in the regressions, but not reported.

\begin{tabular}{|c|c|c|c|c|c|c|c|c|}
\hline & \multicolumn{5}{|c|}{ LC1/Assets } & \multicolumn{3}{|c|}{ LC2/Assets } \\
\hline & \multicolumn{8}{|c|}{ Quarters before failure } \\
\hline & 1 quarter & 2 quarters & 3 quarters & 4 quarters & 1 quarter & 2 quarters & 3 quarters & 4 quarters \\
\hline LC_0-10\% & $\begin{array}{l}0.562^{\star \star} \\
{[0.228]}\end{array}$ & $\begin{array}{c}0.241 \\
{[0.221]}\end{array}$ & $\begin{array}{l}0.474^{\star *} \\
{[0.200]}\end{array}$ & $\begin{array}{c}0.344 \\
{[0.257]}\end{array}$ & $\begin{array}{c}0.861^{\star * \star} \\
{[0.228]}\end{array}$ & $\begin{array}{l}0.432^{\star *} \\
{[0.214]}\end{array}$ & $\begin{array}{c}0.316 \\
{[0.221]}\end{array}$ & $\begin{array}{c}0.224 \\
{[0.277]}\end{array}$ \\
\hline LC_10_20\% & $\begin{array}{l}-0.269 \\
{[0.313]}\end{array}$ & $\begin{array}{l}-0.091 \\
{[0.251]}\end{array}$ & $\begin{array}{l}-0.266 \\
{[0.265]}\end{array}$ & $\begin{array}{c}-0.224 \\
{[0.284]}\end{array}$ & $\begin{array}{l}-0.223 \\
{[0.332]}\end{array}$ & $\begin{array}{c}-0.086 \\
{[0.263]}\end{array}$ & $\begin{array}{c}0.280 \\
{[0.223]}\end{array}$ & $\begin{array}{c}-0.024 \\
{[0.266]}\end{array}$ \\
\hline LC_80_90\% & $\begin{array}{c}0.263 \\
{[0.287]}\end{array}$ & $\begin{array}{l}-0.116 \\
{[0.286]}\end{array}$ & $\begin{array}{c}0.011 \\
{[0.255]}\end{array}$ & $\begin{array}{c}0.132 \\
{[0.281]}\end{array}$ & $\begin{array}{l}0.570^{* *} \\
{[0.264]}\end{array}$ & $\begin{array}{c}0.154 \\
{[0.251]}\end{array}$ & $\begin{array}{c}0.092 \\
{[0.250]}\end{array}$ & $\begin{array}{c}0.409 \\
{[0.264]}\end{array}$ \\
\hline LC_90_100\% & $\begin{array}{l}1.355^{\star * \star} \\
{[0.205]}\end{array}$ & $\begin{array}{l}1.073^{* * *} \\
{[0.186]}\end{array}$ & $\begin{array}{c}0.746^{* * *} \\
{[0.197]}\end{array}$ & $\begin{array}{l}1.093^{* * *} \\
{[0.225]}\end{array}$ & $\begin{array}{l}1.259^{* * *} \\
{[0.212]}\end{array}$ & $\begin{array}{c}0.936^{* * *} \\
{[0.184]}\end{array}$ & $\begin{array}{c}0.865^{\star * *} \\
{[0.183]}\end{array}$ & $\begin{array}{c}1.122^{* * *} \\
{[0.226]}\end{array}$ \\
\hline Size & $\begin{array}{c}-0.255^{* * *} \\
{[0.054]}\end{array}$ & $\begin{array}{c}-0.244^{* * *} \\
{[0.042]}\end{array}$ & $\begin{array}{c}-0.190^{* * *} \\
{[0.041]}\end{array}$ & $\begin{array}{c}-0.294^{* * *} \\
{[0.083]}\end{array}$ & $\begin{array}{c}-0.227^{* * *} \\
{[0.062]}\end{array}$ & $\begin{array}{c}-0.214^{* * *} \\
{[0.041]}\end{array}$ & $\begin{array}{c}-0.178^{* * *} \\
{[0.040]}\end{array}$ & $\begin{array}{c}-0.299^{* * *} \\
{[0.082]}\end{array}$ \\
\hline ROA & $\begin{array}{c}-6.009^{* * *} \\
{[0.962]}\end{array}$ & $\begin{array}{c}-4.598^{* * *} \\
{[0.960]}\end{array}$ & $\begin{array}{c}-3.810^{* * *} \\
{[0.979]}\end{array}$ & $\begin{array}{c}-4.535^{* * *} \\
{[1.484]}\end{array}$ & $\begin{array}{c}-6.278^{* * *} \\
{[1.020]}\end{array}$ & $\begin{array}{c}-4.578^{* * *} \\
{[0.955]}\end{array}$ & $\begin{array}{c}-3.582^{* * *} \\
{[0.964]}\end{array}$ & $\begin{array}{c}-4.190^{* * *} \\
{[1.595]}\end{array}$ \\
\hline $\begin{array}{l}\text { Small business } \\
\text { growth }\end{array}$ & $\begin{array}{l}-0.191 \\
{[0.190]}\end{array}$ & $\begin{array}{l}-0.158 \\
{[0.145]}\end{array}$ & $\begin{array}{l}-0.094 \\
{[0.135]}\end{array}$ & $\begin{array}{l}-0.098 \\
{[0.130]}\end{array}$ & $\begin{array}{l}-0.193 \\
{[0.197]}\end{array}$ & $\begin{array}{l}-0.157 \\
{[0.147]}\end{array}$ & $\begin{array}{l}-0.096 \\
{[0.135]}\end{array}$ & $\begin{array}{l}-0.106 \\
{[0.134]}\end{array}$ \\
\hline $\begin{array}{l}\text { Household } \\
\text { income growth }\end{array}$ & $\begin{array}{c}-0.006 \\
{[0.006]}\end{array}$ & $\begin{array}{l}-0.000 \\
{[0.005]}\end{array}$ & $\begin{array}{c}-0.010^{* *} \\
{[0.005]}\end{array}$ & $\begin{array}{c}-0.001 \\
{[0.006]}\end{array}$ & $\begin{array}{l}-0.006 \\
{[0.006]}\end{array}$ & $\begin{array}{c}-0.000 \\
{[0.005]}\end{array}$ & $\begin{array}{c}-0.010^{* *} \\
{[0.005]}\end{array}$ & $\begin{array}{c}-0.002 \\
{[0.006]}\end{array}$ \\
\hline Constant & $\begin{array}{c}-3.732^{* * *} \\
{[0.937]}\end{array}$ & $\begin{array}{c}-4.159^{* * *} \\
{[0.812]}\end{array}$ & $\begin{array}{c}-2.812^{* * *} \\
{[0.752]}\end{array}$ & $\begin{array}{c}-6.048^{* * *} \\
{[1.131]}\end{array}$ & $\begin{array}{c}-4.191^{* * *} \\
{[1.001]}\end{array}$ & $\begin{array}{c}-4.299^{* * *} \\
{[0.810]}\end{array}$ & $\begin{array}{c}-2.925^{\star * *} \\
{[0.749]}\end{array}$ & $\begin{array}{c}-6.590^{* * *} \\
{[1.102]}\end{array}$ \\
\hline Observations & 35287 & 34966 & 34748 & 34586 & 35287 & 34966 & 34748 & 34586 \\
\hline $\mathrm{Nb}$. of banks & 1386 & 1385 & 1386 & 1385 & 1386 & 1385 & 1386 & 1385 \\
\hline LogLikelihood & -1064.607 & -1246.900 & -1306.426 & -1320.691 & -1065.024 & -1249.922 & -1306.114 & -1320.869 \\
\hline
\end{tabular}




\section{Table 5. Liquidity Creation and Bank Failures: Longer Lags}

Logit estimations are performed under the random effects assumption. The dependent variable is a dummy variable, bank failure that is equal to one when the bank's license is revoked and zero otherwise. $L C 1$ denotes the category-based liquidity creation measure. $L C 2$ is the maturity-based liquidity creation measure. These measures enter into the regressions as dummy variables depending on their distribution across several percentiles. Size is the logarithm of total assets; ROA is return on assets; Small business growth is the growth in regional SMEs; and Household Income Growth is the growth in regional household income per capita. Marginal effects of a change in the relevant explanatory variable are reported. Standard errors appear in square brackets below estimated coefficients. $*, * *, * *$ denote an estimate significantly different from 0 at the $10 \%, 5 \%$, and $1 \%$ level, respectively. Dummy variables for quarters and years are included in the regressions, but not reported.

LC1/Assets

LC2/Assets

Months before failure

15 months 18 months 21 months 24 months 15 months 18 months 21 months 24 months

\begin{tabular}{lcccccccc}
\hline LC_0-10\% & 0.336 & 0.290 & $0.504^{*}$ & 0.232 & 0.314 & 0.309 & $0.532^{* *}$ & -0.142 \\
& {$[0.277]$} & {$[0.260]$} & {$[0.271]$} & {$[0.269]$} & {$[0.271]$} & {$[0.246]$} & {$[0.242]$} & {$[0.319]$} \\
LC_10_20\% & -0.010 & 0.047 & 0.358 & $0.583^{* * *}$ & 0.158 & 0.046 & 0.382 & $0.443^{*}$ \\
& {$[0.278]$} & {$[0.260]$} & {$[0.261]$} & {$[0.226]$} & {$[0.256]$} & {$[0.250]$} & {$[0.233]$} & {$[0.245]$} \\
LC_80_90\% & $0.516^{* *}$ & -0.118 & $0.458^{*}$ & -0.509 & 0.128 & 0.055 & -0.260 & -0.148 \\
& {$[0.255]$} & {$[0.290]$} & {$[0.272]$} & {$[0.346]$} & {$[0.280]$} & {$[0.262]$} & {$[0.309]$} & {$[0.321]$} \\
LC_90_100\% & 0.381 & $0.581^{* *}$ & 0.438 & $0.846^{* * *}$ & $0.820^{* * *}$ & $0.476^{* *}$ & $0.752^{* * *}$ & $0.748^{* * *}$ \\
& {$[0.279]$} & {$[0.247]$} & {$[0.288]$} & {$[0.230]$} & {$[0.238]$} & {$[0.233]$} & {$[0.229]$} & {$[0.268]$} \\
Size & $-0.253^{* * *}$ & $-0.151^{* *}$ & $-0.203^{* * *}$ & $-0.124^{* *}$ & $-0.209^{* * *}$ & $-0.122^{* *}$ & $-0.140^{* *}$ & $-0.164^{* *}$ \\
& {$[0.077]$} & {$[0.063]$} & {$[0.077]$} & {$[0.057]$} & {$[0.071]$} & {$[0.053]$} & {$[0.056]$} & {$[0.074]$} \\
ROA & -3.411 & $-3.623^{*}$ & -0.661 & -0.504 & -3.369 & $-3.768^{* *}$ & -1.103 & 0.675 \\
Small & {$[2.217]$} & {$[1.989]$} & {$[2.319]$} & {$[2.478]$} & {$[2.086]$} & {$[1.843]$} & {$[2.435]$} & {$[2.467]$} \\
business & -0.230 & -0.260 & -0.121 & 0.035 & -0.206 & -0.224 & -0.091 & 0.043 \\
growth & {$[0.180]$} & {$[0.195]$} & {$[0.126]$} & {$[0.079]$} & {$[0.172]$} & {$[0.180]$} & {$[0.114]$} & {$[0.092]$} \\
Household & & & & & & & & $0.032]$ \\
income & -0.001 & 0.003 & 0.006 & 0.002 & -0.001 & 0.003 & 0.006 & 0.002 \\
growth & {$[0.006]$} & {$[0.005]$} & {$[0.006]$} & {$[0.006]$} & {$[0.006]$} & {$[0.005]$} & {$[0.005]$} & {$[0.006]$} \\
Constant & $-8.110^{* * *}$ & $-7.634^{* * *}$ & $-9.955^{* * *}$ & $-5.391^{* * *}$ & $-7.301^{* * *}$ & $-6.899^{* * *}$ & $-7.499^{* * *}$ & $-6.121^{* * *}$ \\
\hline Observations & {$[1.112]$} & {$[1.236]$} & {$[1.388]$} & {$[0.862]$} & {$[1.155]$} & {$[1.058]$} & {$[1.173]$} & {$[0.969]$} \\
Nb. of banks & 1,37386 & 32,304 & 31,268 & 30,207 & 33,386 & 32,304 & 31,268 & 30,207 \\
LogLikelihood & -1270.265 & -1272.710 & -1252.433 & -1202.936 & -1268.539 & -1274.432 & -1250.874 & -1205.025 \\
\hline
\end{tabular}




\section{Table 6. Liquidity Creation and Bank Failures: Alternative Measure of Failure}

Logit estimations are performed under the random effects assumption. The dependent variable is a dummy variable, bank failure that is equal to one when a ratio of equity to total assets is below $2 \%$ and zero otherwise. LC1 denotes the category-based liquidity creation measure. $L C 2$ is the maturity-based liquidity creation measure. These measures enter into the regressions as dummy variables depending on their distribution across several percentiles. Size is the logarithm of total assets; ROA is return on assets; Small business growth is the growth in regional SMEs; and Household Income Growth is the growth in regional household income per capita. Marginal effects of a change in the relevant explanatory variable are reported. Standard errors appear in square brackets below estimated coefficients. ${ }^{*}, * *, * * *$ denote an estimate significantly different from 0 at the $10 \%, 5 \%$, and $1 \%$ level, respectively. Dummy variables for quarters and years are included in the regressions, but not reported.

\begin{tabular}{|c|c|c|c|c|c|c|c|c|}
\hline & \multicolumn{4}{|c|}{ LC1/Assets } & \multicolumn{4}{|c|}{ LC2/Assets } \\
\hline & \multicolumn{8}{|c|}{ Quarters before failure } \\
\hline & 1 quarter & 2 quarters & 3 quarters & 4 quarters & 1 quarter & 2 quarters & 3 quarters & 4 quarters \\
\hline LC_0-10\% & $\begin{array}{c}0.145 \\
{[0.630]}\end{array}$ & $\begin{array}{c}0.139 \\
{[0.629]}\end{array}$ & $\begin{array}{l}1.028^{* *} \\
{[0.489]}\end{array}$ & $\begin{array}{l}-0.257 \\
{[0.751]}\end{array}$ & $\begin{array}{l}-1.116 \\
{[1.027]}\end{array}$ & $\begin{array}{l}-0.022 \\
{[0.621]}\end{array}$ & $\begin{array}{c}0.757 \\
{[0.471]}\end{array}$ & $\begin{array}{l}-0.547 \\
{[0.740]}\end{array}$ \\
\hline LC_10_20\% & $\begin{array}{l}-0.975 \\
{[1.031]}\end{array}$ & $\begin{array}{c}0.082 \\
{[0.628]}\end{array}$ & $\begin{array}{l}-0.168 \\
{[0.756]}\end{array}$ & $\begin{array}{c}0.628 \\
{[0.513]}\end{array}$ & $\begin{array}{c}0.473 \\
{[0.503]}\end{array}$ & $\begin{array}{c}0.210 \\
{[0.549]}\end{array}$ & $\begin{array}{l}-0.445 \\
{[0.744]}\end{array}$ & $\begin{array}{c}0.119 \\
{[0.545]}\end{array}$ \\
\hline LC_80_90\% & $\begin{array}{c}0.278 \\
{[0.560]}\end{array}$ & $\begin{array}{c}0.240 \\
{[0.557]}\end{array}$ & $\begin{array}{c}0.110 \\
{[0.637]}\end{array}$ & $\begin{array}{l}0.939^{* *} \\
{[0.436]}\end{array}$ & $\begin{array}{c}0.147 \\
{[0.550]}\end{array}$ & $\begin{array}{l}-0.598 \\
{[0.742]}\end{array}$ & $\begin{array}{l}-0.573 \\
{[0.744]}\end{array}$ & $\begin{array}{c}0.562 \\
{[0.435]}\end{array}$ \\
\hline LC_90_100\% & $\begin{array}{l}1.906^{* * *} \\
{[0.340]}\end{array}$ & $\begin{array}{l}1.622^{* * *} \\
{[0.356]}\end{array}$ & $\begin{array}{c}2.056^{* * *} \\
{[0.356]}\end{array}$ & $\begin{array}{l}1.619^{* * *} \\
{[0.373]}\end{array}$ & $\begin{array}{l}1.498^{* * *} \\
{[0.343]}\end{array}$ & $\begin{array}{l}1.401^{* * *} \\
{[0.350]}\end{array}$ & $\begin{array}{l}1.569^{* * *} \\
{[0.342]}\end{array}$ & $\begin{array}{l}1.055^{\star * *} \\
{[0.376]}\end{array}$ \\
\hline Size & $\begin{array}{c}0.084 \\
{[0.079]}\end{array}$ & $\begin{array}{c}0.097 \\
{[0.081]}\end{array}$ & $\begin{array}{c}0.094 \\
{[0.078]}\end{array}$ & $\begin{array}{l}0.128^{*} \\
{[0.075]}\end{array}$ & $\begin{array}{l}0.168^{* *} \\
{[0.079]}\end{array}$ & $\begin{array}{l}0.158^{* *} \\
{[0.080]}\end{array}$ & $\begin{array}{l}0.170^{* *} \\
{[0.078]}\end{array}$ & $\begin{array}{c}0.195^{* * *} \\
{[0.074]}\end{array}$ \\
\hline ROA & $\begin{array}{c}-2.984^{* * *} \\
{[0.886]}\end{array}$ & $\begin{array}{c}-3.263^{* *} \\
{[1.280]}\end{array}$ & $\begin{array}{c}-4.143^{* *} \\
{[2.022]}\end{array}$ & $\begin{array}{c}-3.958^{* *} \\
{[1.629]}\end{array}$ & $\begin{array}{c}-3.347^{* * *} \\
{[0.910]}\end{array}$ & $\begin{array}{c}-3.370^{* * *} \\
{[1.265]}\end{array}$ & $\begin{array}{c}-4.247^{* *} \\
{[1.851]}\end{array}$ & $\begin{array}{c}-4.665^{\star * *} \\
{[1.591]}\end{array}$ \\
\hline $\begin{array}{l}\text { Small business } \\
\text { growth }\end{array}$ & $\begin{array}{l}-0.082 \\
{[0.548]}\end{array}$ & $\begin{array}{l}-0.112 \\
{[0.599]}\end{array}$ & $\begin{array}{l}-0.231 \\
{[0.670]}\end{array}$ & $\begin{array}{c}0.106 \\
{[0.298]}\end{array}$ & $\begin{array}{l}-0.042 \\
{[0.486]}\end{array}$ & $\begin{array}{l}-0.078 \\
{[0.565]}\end{array}$ & $\begin{array}{l}-0.162 \\
{[0.670]}\end{array}$ & $\begin{array}{c}0.116 \\
{[0.280]}\end{array}$ \\
\hline $\begin{array}{l}\text { Household } \\
\text { income growth }\end{array}$ & $\begin{array}{c}0.013 \\
{[0.011]}\end{array}$ & $\begin{array}{c}0.009 \\
{[0.009]}\end{array}$ & $\begin{array}{c}0.008 \\
{[0.007]}\end{array}$ & $\begin{array}{c}0.009 \\
{[0.010]}\end{array}$ & $\begin{array}{c}0.013 \\
{[0.010]}\end{array}$ & $\begin{array}{c}0.009 \\
{[0.009]}\end{array}$ & $\begin{array}{c}0.008 \\
{[0.007]}\end{array}$ & $\begin{array}{c}0.009 \\
{[0.010]}\end{array}$ \\
\hline Constant & $\begin{array}{c}-6.567^{\star * *} \\
{[1.526]}\end{array}$ & $\begin{array}{c}-6.201^{* * *} \\
{[1.534]}\end{array}$ & $\begin{array}{c}-6.349^{* * *} \\
{[1.285]}\end{array}$ & $\begin{array}{c}-6.638^{\star * *} \\
{[1.639]}\end{array}$ & $\begin{array}{c}-6.925^{\star * *} \\
{[1.489]}\end{array}$ & $\begin{array}{c}-6.422^{\star * \star} \\
{[1.515]}\end{array}$ & $\begin{array}{c}-6.392^{\star * *} \\
{[1.268]}\end{array}$ & $\begin{array}{c}-6.625^{\star * \star} \\
{[1.623]}\end{array}$ \\
\hline Observations & 35,287 & 34,966 & 34,748 & 34,586 & 35,287 & 34,966 & 34,748 & 34,586 \\
\hline $\mathrm{Nb}$. of banks & 1,386 & 1,385 & 1,386 & 1,385 & 1,386 & 1,385 & 1,386 & 1,385 \\
\hline LogLikelihood & -266.612 & -263.572 & -265.658 & -282.729 & -273.146 & -265.007 & -271.644 & -287.834 \\
\hline
\end{tabular}




\section{Table 7. Liquidity Creation and Bank Failures: Moscow Banks Only}

Logit estimations are performed under the random effects assumption. The dependent variable is a dummy variable, bank failure that is equal to one when the bank's license is revoked and zero otherwise. $L C 1$ denotes the category-based liquidity creation measure. $L C 2$ is the maturity-based liquidity creation measure. These measures enter into the regressions as dummy variables depending on their distribution across several percentiles. Size is the logarithm of total assets; ROA is return on assets; Small business growth is the growth in regional SMEs; and Household Income Growth is the growth in regional household income per capita. Marginal effects of a change in the relevant explanatory variable are reported. Standard errors appear in square brackets below estimated coefficients. ${ }^{*}, * *, * * *$ denote an estimate significantly different from 0 at the $10 \%, 5 \%$, and $1 \%$ level, respectively. As we only consider banks located in Moscow, we skip the regional variables Small business growth and Household income growth from the estimations. Dummy variables for quarters and years are included in the regressions, but not reported.

\begin{tabular}{lcccccccc}
\hline \multicolumn{1}{c}{ LC1/Assets } \\
\multicolumn{1}{c}{} & \multicolumn{7}{c}{ LC2/Assets } \\
& 1 quarter & 2 quarters & 3 quarters & 4 quarters & 1 quarter & 2 quarters & 3 quarters & 4 quarters \\
\hline LC_0-10\% & 0.109 & -0.214 & -0.004 & -0.268 & 0.450 & 0.168 & -0.082 & -0.135 \\
& {$[0.288]$} & {$[0.295]$} & {$[0.255]$} & {$[0.290]$} & {$[0.275]$} & {$[0.267]$} & {$[0.274]$} & {$[0.279]$} \\
LC_10_20\% & $-0.672^{*}$ & -0.197 & $-0.791^{* *}$ & -0.236 & -0.498 & -0.516 & -0.147 & -0.234 \\
& {$[0.406]$} & {$[0.299]$} & {$[0.356]$} & {$[0.287]$} & {$[0.407]$} & {$[0.359]$} & {$[0.286]$} & {$[0.294]$} \\
LC_80_90\% & 0.224 & -0.163 & -0.056 & -0.351 & $0.664^{* *}$ & 0.300 & 0.157 & 0.027 \\
& {$[0.366]$} & {$[0.379]$} & {$[0.327]$} & {$[0.376]$} & {$[0.326]$} & {$[0.330]$} & {$[0.326]$} & {$[0.339]$} \\
LC_90_100\% & $1.229^{* * *}$ & $1.111^{* * *}$ & $0.721^{* * *}$ & $1.096^{* * *}$ & $1.305^{* * *}$ & $1.189^{* * *}$ & $0.937^{* * *}$ & $1.083^{* * *}$ \\
& {$[0.248]$} & {$[0.228]$} & {$[0.237]$} & {$[0.215]$} & {$[0.250]$} & {$[0.228]$} & {$[0.232]$} & {$[0.220]$} \\
Size & $-0.412^{* * *}$ & $-0.382^{* * *}$ & $-0.320^{* * *}$ & $-0.319^{* * *}$ & $-0.343^{* * *}$ & $-0.326^{* * *}$ & $-0.283^{* * *}$ & $-0.259^{* * *}$ \\
& {$[0.065]$} & {$[0.060]$} & {$[0.057]$} & {$[0.055]$} & {$[0.062]$} & {$[0.057]$} & {$[0.055]$} & {$[0.053]$} \\
ROA & $-6.112^{* * *}$ & $-6.019^{* * *}$ & $-5.321^{* *}$ & -3.246 & $-6.126^{* * *}$ & $-6.047^{* * *}$ & $-5.279^{* * *}$ & -3.500 \\
& {$[1.238]$} & {$[1.600]$} & {$[2.075]$} & {$[2.200]$} & {$[1.265]$} & {$[1.601]$} & {$[2.051]$} & {$[2.170]$} \\
Constant & $-3.315^{* * *}$ & $-3.321^{* * *}$ & $-3.342^{* * *}$ & $-3.303^{* * *}$ & $-3.736^{* * *}$ & $-3.641^{* * *}$ & $-3.605^{* * *}$ & $-3.589^{* * *}$ \\
& {$[0.433]$} & {$[0.397]$} & {$[0.378]$} & {$[0.360]$} & {$[0.439]$} & {$[0.401]$} & {$[0.380]$} & {$[0.363]$} \\
\hline Observations & 16,240 & 16,029 & 15,886 & 15,776 & 16,240 & 16,029 & 15,886 & 15,776 \\
Nb. of banks & 687 & 686 & 687 & 688 & 687 & 686 & 687 & 688 \\
LogLikelihood & -622.767 & -726.726 & -785.342 & -791.344 & -621.534 & -724.953 & -785.836 & -794.056 \\
\hline
\end{tabular}




\section{Table 8. Liquidity Creation and Bank Failures: Domestic Private Banks Only}

Logit estimations are performed under the random effects assumption. The dependent variable is a dummy variable, bank failure that is equal to one when the bank's license is revoked and zero otherwise. $L C 1$ denotes the category-based liquidity creation measure. $L C 2$ is the maturity-based liquidity creation measure. These measures enter into the regressions as dummy variables depending on their distribution across several percentiles. Size is the logarithm of total assets; ROA is return on assets; Small business growth is the growth in regional SMEs; and Household Income Growth is the growth in regional household income per capita. Marginal effects of a change in the relevant explanatory variable are reported. Standard errors appear in square brackets below estimated coefficients. $*, * *, * *$ denote an estimate significantly different from 0 at the $10 \%, 5 \%$, and $1 \%$ level, respectively. Dummy variables for quarters and years are included in the regressions, but not reported.

\begin{tabular}{lcccccccc}
\hline & \multicolumn{7}{c}{ LC1/Assets } \\
\hline & & \multicolumn{7}{c}{ Quarters before failure } \\
& 1 quarter & 2 quarters & 3 quarters & 4 quarters & 1 quarter & 2 quarters & 3 quarters & 4 quarters \\
\hline LC_0-10\% & $0.611^{* * *}$ & 0.290 & $0.529^{* * *}$ & $0.422^{*}$ & $0.950^{* * *}$ & $0.521^{* *}$ & $0.411^{*}$ & 0.269 \\
& {$[0.229]$} & {$[0.221]$} & {$[0.201]$} & {$[0.247]$} & {$[0.228]$} & {$[0.215]$} & {$[0.222]$} & {$[0.293]$} \\
LC_10_20\% & -0.247 & -0.070 & -0.245 & -0.174 & -0.202 & -0.070 & 0.295 & -0.066 \\
& {$[0.313]$} & {$[0.252]$} & {$[0.265]$} & {$[0.276]$} & {$[0.331]$} & {$[0.264]$} & {$[0.224]$} & {$[0.274]$} \\
LC_80_90\% & 0.252 & -0.130 & -0.002 & 0.116 & $0.573^{* *}$ & 0.162 & 0.102 & $0.452^{*}$ \\
& {$[0.287]$} & {$[0.286]$} & {$[0.256]$} & {$[0.276]$} & {$[0.263]$} & {$[0.251]$} & {$[0.250]$} & {$[0.274]$} \\
LC_90_100\% & $1.361^{* * *}$ & $1.078^{* * *}$ & $0.750^{* * *}$ & $1.090^{* * *}$ & $1.247^{* * *}$ & $0.929^{* * *}$ & $0.858^{* * *}$ & $1.111^{* * *}$ \\
& {$[0.207]$} & {$[0.186]$} & {$[0.197]$} & {$[0.217]$} & {$[0.211]$} & {$[0.185]$} & {$[0.183]$} & {$[0.241]$} \\
Size & $-0.223^{* * *}$ & $-0.213^{* * *}$ & $-0.156^{* * *}$ & $-0.215^{* * *}$ & $-0.190^{* * *}$ & $-0.184^{* * *}$ & $-0.145^{* * *}$ & $-0.338^{* * *}$ \\
& {$[0.055]$} & {$[0.043]$} & {$[0.042]$} & {$[0.063]$} & {$[0.060]$} & {$[0.042]$} & {$[0.041]$} & {$[0.072]$} \\
ROA & $-6.027^{* * *}$ & $-4.594^{* * *}$ & $-3.862^{* * *}$ & $-4.659^{* * *}$ & $-6.261^{* * *}$ & $-4.586^{* * *}$ & $-3.644^{* * *}$ & $-3.948^{* *}$ \\
& {$[0.978]$} & {$[0.970]$} & {$[0.981]$} & {$[1.429]$} & {$[1.030]$} & {$[0.964]$} & {$[0.966]$} & {$[1.762]$} \\
Small business & -0.191 & -0.158 & -0.093 & -0.091 & -0.193 & -0.156 & -0.096 & -0.127 \\
growth & {$[0.192]$} & {$[0.146]$} & {$[0.135]$} & {$[0.126]$} & {$[0.197]$} & {$[0.147]$} & {$[0.136]$} & {$[0.148]$} \\
Household & -0.006 & -0.001 & $-0.011^{* *}$ & -0.002 & -0.006 & -0.001 & $-0.011^{* *}$ & -0.003 \\
income growth & {$[0.006]$} & {$[0.005]$} & {$[0.005]$} & {$[0.005]$} & {$[0.006]$} & {$[0.005]$} & {$[0.005]$} & {$[0.006]$} \\
Constant & $-3.846^{* * *}$ & $-4.251^{* * *}$ & $-2.905^{* * *}$ & $-5.826^{* * *}$ & $-4.274^{* * *}$ & $-4.391^{* * *}$ & $-3.018^{* * *}$ & $-8.416^{* * *}$ \\
\hline Observations & {$[0.953]$} & {$[0.814]$} & {$[0.755]$} & {$[0.955]$} & {$[1.016]$} & {$[0.812]$} & {$[0.752]$} & {$[1.049]$} \\
Nb. of banks & 33,097 & 32,802 & 32,598 & 32,450 & 33,097 & 32,802 & 32,598 & 32,450 \\
\hline & 1,322 & 1,322 & 1,323 & 1,322 & 1,322 & 1,322 & 1,323 & 1,322 \\
& -1056.115 & -1236.839 & -1294.782 & -1306.472 & -1056.127 & -1239.791 & -1294.767 & -1296.410 \\
\hline
\end{tabular}




\section{Table 9. Liquidity Creation and Bank Failures: Effect of Deposit Insurance}

Logit estimations are performed under the random effects assumption. The dependent variable is a dummy variable, bank failure that is equal to one when the bank's license is revoked and zero otherwise. $L C 1$ denotes the category-based liquidity creation measure. $L C 2$ is the maturity-based liquidity creation measure. These measures enter into the regressions as dummy variables depending on their distribution across several percentiles. Size is the logarithm of total assets; ROA is return on assets; Small business growth is the growth in regional SMEs; and Household Income Growth is the growth in regional household income per capita. Marginal effects of a change in the relevant explanatory variable are reported. Standard errors appear in square brackets below estimated coefficients. *, **,*** denote an estimate significantly different from 0 at the $10 \%, 5 \%$, and $1 \%$ level, respectively. We include here the dummy variable Deposit Insurance, which is equal to one for the quarters after the implementation of deposit insurance scheme in 2004. Dummy variables for quarters and years are included in the regressions, but not reported.

\begin{tabular}{|c|c|c|c|c|c|c|c|c|}
\hline & \multicolumn{5}{|c|}{ LC1/Assets } & \multicolumn{3}{|c|}{ LC2/Assets } \\
\hline & \multicolumn{8}{|c|}{ Quarters before failure } \\
\hline & 1 quarter & 2 quarters & 3 quarters & 4 quarters & 1 quarter & 2 quarters & 3 quarters & 4 quarters \\
\hline LC_0-10\% & $\begin{array}{l}0.561^{* *} \\
{[0.228]}\end{array}$ & $\begin{array}{c}0.242 \\
{[0.221]}\end{array}$ & $\begin{array}{l}0.472^{* *} \\
{[0.200]}\end{array}$ & $\begin{array}{c}0.344 \\
{[0.257]}\end{array}$ & $\begin{array}{c}0.852^{* * *} \\
{[0.222]}\end{array}$ & $\begin{array}{l}0.433^{* *} \\
{[0.214]}\end{array}$ & $\begin{array}{c}0.314 \\
{[0.221]}\end{array}$ & $\begin{array}{c}0.224 \\
{[0.277]}\end{array}$ \\
\hline LC_10_20\% & $\begin{array}{l}-0.270 \\
{[0.312]}\end{array}$ & $\begin{array}{l}-0.090 \\
{[0.251]}\end{array}$ & $\begin{array}{l}-0.267 \\
{[0.265]}\end{array}$ & $\begin{array}{l}-0.224 \\
{[0.284]}\end{array}$ & $\begin{array}{l}-0.214 \\
{[0.328]}\end{array}$ & $\begin{array}{l}-0.085 \\
{[0.263]}\end{array}$ & $\begin{array}{c}0.278 \\
{[0.223]}\end{array}$ & $\begin{array}{l}-0.024 \\
{[0.266]}\end{array}$ \\
\hline LC_80_90\% & $\begin{array}{c}0.263 \\
{[0.287]}\end{array}$ & $\begin{array}{l}-0.117 \\
{[0.286]}\end{array}$ & $\begin{array}{c}0.011 \\
{[0.255]}\end{array}$ & $\begin{array}{c}0.132 \\
{[0.281]}\end{array}$ & $\begin{array}{l}0.556^{* *} \\
{[0.256]}\end{array}$ & $\begin{array}{c}0.154 \\
{[0.251]}\end{array}$ & $\begin{array}{c}0.092 \\
{[0.250]}\end{array}$ & $\begin{array}{c}0.409 \\
{[0.264]}\end{array}$ \\
\hline LC_90_100\% & $\begin{array}{l}1.354^{\star \star *} \\
{[0.205]}\end{array}$ & $\begin{array}{l}1.073^{\star \star \star} \\
{[0.186]}\end{array}$ & $\begin{array}{l}0.745^{\star \star *} \\
{[0.197]}\end{array}$ & $\begin{array}{l}1.093^{\star \star *} \\
{[0.225]}\end{array}$ & $\begin{array}{l}1.244^{\star * *} \\
{[0.201]}\end{array}$ & $\begin{array}{c}0.936^{\star * \star} \\
{[0.184]}\end{array}$ & $\begin{array}{c}0.865^{\star \star *} \\
{[0.183]}\end{array}$ & $\begin{array}{l}1.122^{\star \star *} \\
{[0.226]}\end{array}$ \\
\hline Size & $\begin{array}{c}-0.255^{\star \star \star} \\
{[0.054]}\end{array}$ & $\begin{array}{c}-0.245^{\star * *} \\
{[0.042]}\end{array}$ & $\begin{array}{c}-0.190^{* \star *} \\
{[0.041]}\end{array}$ & $\begin{array}{c}-0.294^{\star * *} \\
{[0.083]}\end{array}$ & $\begin{array}{c}-0.217^{\star * *} \\
{[0.048]}\end{array}$ & $\begin{array}{c}-0.215^{\star * *} \\
{[0.041]}\end{array}$ & $\begin{array}{c}-0.177^{\star * *} \\
{[0.040]}\end{array}$ & $\begin{array}{c}-0.299^{* * *} \\
{[0.082]}\end{array}$ \\
\hline ROA & $\begin{array}{c}-6.008^{* * *} \\
{[0.962]}\end{array}$ & $\begin{array}{c}-4.591^{* * *} \\
{[0.960]}\end{array}$ & $\begin{array}{c}-3.800^{* * *} \\
{[0.982]}\end{array}$ & $\begin{array}{c}-4.535^{\star * *} \\
{[1.484]}\end{array}$ & $\begin{array}{c}-6.130^{* \star *} \\
{[0.842]}\end{array}$ & $\begin{array}{c}-4.572^{\star * *} \\
{[0.955]}\end{array}$ & $\begin{array}{c}-3.572^{\star * \star} \\
{[0.966]}\end{array}$ & $\begin{array}{c}-4.190^{\star \star *} \\
{[1.595]}\end{array}$ \\
\hline $\begin{array}{l}\text { Small business } \\
\text { growth }\end{array}$ & $\begin{array}{l}-0.197 \\
{[0.192]}\end{array}$ & $\begin{array}{l}-0.154 \\
{[0.144]}\end{array}$ & $\begin{array}{l}-0.095 \\
{[0.136]}\end{array}$ & $\begin{array}{l}-0.098 \\
{[0.130]}\end{array}$ & $\begin{array}{l}-0.197 \\
{[0.196]}\end{array}$ & $\begin{array}{l}-0.153 \\
{[0.146]}\end{array}$ & $\begin{array}{l}-0.098 \\
{[0.137]}\end{array}$ & $\begin{array}{l}-0.106 \\
{[0.134]}\end{array}$ \\
\hline $\begin{array}{l}\text { Household } \\
\text { income growth }\end{array}$ & $\begin{array}{l}-0.005 \\
{[0.007]}\end{array}$ & $\begin{array}{l}-0.002 \\
{[0.006]}\end{array}$ & $\begin{array}{l}-0.009^{*} \\
{[0.005]}\end{array}$ & $\begin{array}{l}-0.001 \\
{[0.006]}\end{array}$ & $\begin{array}{l}-0.005 \\
{[0.006]}\end{array}$ & $\begin{array}{l}-0.002 \\
{[0.006]}\end{array}$ & $\begin{array}{l}-0.009^{*} \\
{[0.005]}\end{array}$ & $\begin{array}{l}-0.002 \\
{[0.006]}\end{array}$ \\
\hline $\begin{array}{l}\text { Deposit } \\
\text { insurance }\end{array}$ & $\begin{array}{l}-0.220 \\
{[0.478]}\end{array}$ & $\begin{array}{c}0.281 \\
{[0.378]}\end{array}$ & $\begin{array}{l}-0.433 \\
{[0.488]}\end{array}$ & $\begin{array}{c}0.000 \\
{[0.000]}\end{array}$ & $\begin{array}{l}-0.210 \\
{[0.478]}\end{array}$ & $\begin{array}{c}0.280 \\
{[0.378]}\end{array}$ & $\begin{array}{l}-0.439 \\
{[0.488]}\end{array}$ & $\begin{array}{c}0.000 \\
{[0.000]}\end{array}$ \\
\hline Constant & $\begin{array}{c}-3.912^{\star \star *} \\
{[1.021]}\end{array}$ & $\begin{array}{c}-3.939^{* * *} \\
{[0.862]}\end{array}$ & $\begin{array}{c}-2.981^{\star * *} \\
{[0.780]}\end{array}$ & $\begin{array}{c}-6.048^{\star * *} \\
{[1.131]}\end{array}$ & $\begin{array}{c}-4.230^{\star * *} \\
{[0.955]}\end{array}$ & $\begin{array}{c}-4.083^{\star * *} \\
{[0.859]}\end{array}$ & $\begin{array}{c}-3.094^{\star * *} \\
{[0.777]}\end{array}$ & $\begin{array}{c}-6.590^{\star * *} \\
{[1.102]}\end{array}$ \\
\hline Observations & 35,287 & 34,966 & 34,748 & 34,586 & 35,287 & 34,966 & 34,748 & 34,586 \\
\hline Nb. of banks & 1,386 & 1,385 & 1,386 & 1,385 & 1,386 & 1,385 & 1,386 & 1,385 \\
\hline LogLikelihood & -1064.503 & -1246.620 & -1306.006 & -1320.691 & -1064.972 & -1249.645 & -1305.682 & -1320.869 \\
\hline
\end{tabular}




\section{Table 10. Liquidity Creation and Bank Failures: Effect of Bank Concentration}

Logit estimations are performed under the random effects assumption. The dependent variable is a dummy variable, bank failure that is equal to one when the bank's license is revoked and zero otherwise. $L C 1$ denotes the category-based liquidity creation measure. $L C 2$ is the maturity-based liquidity creation measure. These measures enter into the regressions as dummy variables depending on their distribution across several percentiles. Size is the logarithm of total assets; ROA is return on assets; Small business growth is the growth in regional SMEs; Household Income Growth is the growth in regional household income per capita, and Herfindahl is regional bank concentration measured by the Herfindahl-Hirschman index. Marginal effects of a change in the relevant explanatory variable are reported. Standard errors appear in square brackets below estimated coefficients. *, **, *** denote an estimate significantly different from 0 at the $10 \%, 5 \%$, and $1 \%$ level, respectively. Dummy variables for quarters and years are included in the regressions, but not reported.

\begin{tabular}{|c|c|c|c|c|c|c|c|c|}
\hline & \multicolumn{4}{|c|}{ LC1/Assets } & \multicolumn{4}{|c|}{ LC2/Assets } \\
\hline & \multicolumn{8}{|c|}{ Quarters before failure } \\
\hline & 1 quarter & 2 quarters & 3 quarters & 4 quarters & 1 quarter & 2 quarters & 3 quarters & 4 quarters \\
\hline LC_0-10\% & $\begin{array}{c}0.367 \\
{[0.227]}\end{array}$ & $\begin{array}{c}0.048 \\
{[0.223]}\end{array}$ & $\begin{array}{c}0.267 \\
{[0.202]}\end{array}$ & $\begin{array}{c}0.272 \\
{[0.210]}\end{array}$ & $\begin{array}{c}0.653^{\star * \star} \\
{[0.218]}\end{array}$ & $\begin{array}{c}0.247 \\
{[0.215]}\end{array}$ & $\begin{array}{c}0.111 \\
{[0.223]}\end{array}$ & $\begin{array}{c}0.131 \\
{[0.226]}\end{array}$ \\
\hline LC_10_20\% & $\begin{array}{l}-0.379 \\
{[0.308]}\end{array}$ & $\begin{array}{l}-0.221 \\
{[0.252]}\end{array}$ & $\begin{array}{l}-0.396 \\
{[0.264]}\end{array}$ & $\begin{array}{l}-0.213 \\
{[0.251]}\end{array}$ & $\begin{array}{l}-0.341 \\
{[0.326]}\end{array}$ & $\begin{array}{l}-0.224 \\
{[0.264]}\end{array}$ & $\begin{array}{c}0.127 \\
{[0.225]}\end{array}$ & $\begin{array}{c}0.071 \\
{[0.233]}\end{array}$ \\
\hline LC_80_90\% & $\begin{array}{c}0.324 \\
{[0.284]}\end{array}$ & $\begin{array}{l}-0.057 \\
{[0.287]}\end{array}$ & $\begin{array}{c}0.067 \\
{[0.256]}\end{array}$ & $\begin{array}{c}0.085 \\
{[0.256]}\end{array}$ & $\begin{array}{l}0.648^{* *} \\
{[0.254]}\end{array}$ & $\begin{array}{c}0.260 \\
{[0.252]}\end{array}$ & $\begin{array}{c}0.197 \\
{[0.250]}\end{array}$ & $\begin{array}{c}0.333 \\
{[0.236]}\end{array}$ \\
\hline LC_90_100\% & $\begin{array}{l}1.370^{* * *} \\
{[0.197]}\end{array}$ & $\begin{array}{l}1.098^{* * *} \\
{[0.186]}\end{array}$ & $\begin{array}{c}0.762^{* * *} \\
{[0.198]}\end{array}$ & $\begin{array}{l}1.031^{* * *} \\
{[0.183]}\end{array}$ & $\begin{array}{l}1.290^{* * *} \\
{[0.196]}\end{array}$ & $\begin{array}{c}0.996^{* * *} \\
{[0.185]}\end{array}$ & $\begin{array}{c}0.914^{* * *} \\
{[0.184]}\end{array}$ & $\begin{array}{l}1.059^{* * *} \\
{[0.177]}\end{array}$ \\
\hline Size & $\begin{array}{c}-0.360^{* * *} \\
{[0.051]}\end{array}$ & $\begin{array}{l}-0.352^{* * *} \\
{[0.047]}\end{array}$ & $\begin{array}{c}-0.294^{* * *} \\
{[0.045]}\end{array}$ & $\begin{array}{l}-0.261^{* * *} \\
{[0.044]}\end{array}$ & $\begin{array}{c}-0.315^{\star * *} \\
{[0.050]}\end{array}$ & $\begin{array}{c}-0.318^{* * *} \\
{[0.045]}\end{array}$ & $\begin{array}{c}-0.280^{* * *} \\
{[0.044]}\end{array}$ & $\begin{array}{c}-0.239^{* * *} \\
{[0.043]}\end{array}$ \\
\hline ROA & $\begin{array}{c}-5.635^{\star * *} \\
{[0.726]}\end{array}$ & $\begin{array}{c}-4.223^{* * *} \\
{[0.959]}\end{array}$ & $\begin{array}{c}-3.922^{* * *} \\
{[0.997]}\end{array}$ & $\begin{array}{c}-3.930^{* * *} \\
{[1.106]}\end{array}$ & $\begin{array}{c}-5.656^{* * *} \\
{[0.740]}\end{array}$ & $\begin{array}{c}-4.173^{* * *} \\
{[0.955]}\end{array}$ & $\begin{array}{c}-3.632^{* * *} \\
{[1.006]}\end{array}$ & $\begin{array}{c}-3.779^{* * *} \\
{[1.103]}\end{array}$ \\
\hline $\begin{array}{l}\text { Small business } \\
\text { growth }\end{array}$ & $\begin{array}{l}-0.135 \\
{[0.222]}\end{array}$ & $\begin{array}{l}-0.103 \\
{[0.162]}\end{array}$ & $\begin{array}{l}-0.045 \\
{[0.155]}\end{array}$ & $\begin{array}{l}-0.012 \\
{[0.118]}\end{array}$ & $\begin{array}{l}-0.140 \\
{[0.231]}\end{array}$ & $\begin{array}{l}-0.103 \\
{[0.165]}\end{array}$ & $\begin{array}{l}-0.049 \\
{[0.157]}\end{array}$ & $\begin{array}{l}-0.014 \\
{[0.120]}\end{array}$ \\
\hline $\begin{array}{l}\text { Household } \\
\text { income growth }\end{array}$ & $\begin{array}{l}-0.007 \\
{[0.006]}\end{array}$ & $\begin{array}{c}0.000 \\
{[0.006]}\end{array}$ & $\begin{array}{l}-0.010^{*} \\
{[0.005]}\end{array}$ & $\begin{array}{l}-0.000 \\
{[0.005]}\end{array}$ & $\begin{array}{l}-0.007 \\
{[0.006]}\end{array}$ & $\begin{array}{l}-0.000 \\
{[0.006]}\end{array}$ & $\begin{array}{l}-0.010^{*} \\
{[0.005]}\end{array}$ & $\begin{array}{l}-0.000 \\
{[0.005]}\end{array}$ \\
\hline Herfindahl index & $\begin{array}{c}-3.933^{* * *} \\
{[0.659]}\end{array}$ & $\begin{array}{c}-3.615^{\star * *} \\
{[0.590]}\end{array}$ & $\begin{array}{c}-3.645^{\star * *} \\
{[0.573]}\end{array}$ & $\begin{array}{c}-3.464^{* * *} \\
{[0.558]}\end{array}$ & $\begin{array}{c}-4.018^{* * *} \\
{[0.663]}\end{array}$ & $\begin{array}{c}-3.672^{* * *} \\
{[0.592]}\end{array}$ & $\begin{array}{c}-3.731^{* * *} \\
{[0.576]}\end{array}$ & $\begin{array}{c}-3.592^{* * *} \\
{[0.562]}\end{array}$ \\
\hline Constant & $\begin{array}{c}-2.411^{* * *} \\
{[0.917]}\end{array}$ & $\begin{array}{c}-3.157^{* * *} \\
{[0.851]}\end{array}$ & $\begin{array}{c}-1.848^{* *} \\
{[0.814]}\end{array}$ & $\begin{array}{c}-3.424^{* * *} \\
{[0.875]}\end{array}$ & $\begin{array}{c}-2.634^{* * *} \\
{[0.914]}\end{array}$ & $\begin{array}{c}-3.306^{* * *} \\
{[0.851]}\end{array}$ & $\begin{array}{c}-1.957^{* *} \\
{[0.813]}\end{array}$ & $\begin{array}{c}-3.548^{* * *} \\
{[0.873]}\end{array}$ \\
\hline Observations & 35,287 & 34,966 & 34,748 & 34,586 & 35,287 & 34,966 & 34,748 & 34,586 \\
\hline Nb. of banks & 1,386 & 1,385 & 1,386 & 1,385 & 1,386 & 1,385 & 1,386 & 1,385 \\
\hline LogLikelihood & -1042.729 & -1224.165 & -1281.603 & -1297.921 & -1042.625 & -1226.653 & -1280.354 & -1297.686 \\
\hline
\end{tabular}

